\title{
Geochemical and petrographic identification of stone quarries used for the construction of the Anahita Temple of Kangavar (West Iran)

\author{
Atefeh Shekofteh ${ }^{1}$, Omid Oudbashi ${ }^{1 *} \mathbb{C}$, Giuseppe Cultrone ${ }^{2}$ and Masoud Ansari ${ }^{1}$
}

\begin{abstract}
The archaeological site of the Anahita Temple in Kangavar is one of the best-known stone monuments in western Iran and dates back to the Persian Empire period of Iranian history (about $550 \mathrm{BC}$ to $650 \mathrm{AD}$ ). The Temple was constructed on a semi-artificial hill out of large stone blocks, many of which are cubic in shape, and short thick columns. In the Kangavar area (basin) there are various sites in which there is evidence of stone extraction. The aim of this paper is to characterize the stones used in the Anahita Temple of Kangavar and their correlations with the quarrying activities observed in the Kangavar regions. In fact, we tried to find out which of these quarries may have been the source of the stone blocks used in the construction of the Anahita Temple. To this end the stones used in the Temple have been characterized by conducting a multi-analytical study involving chemical, mineralogical and textural analyses including XRF, XRD and thin section petrography. The results show that although all the quarries could have provided the stone used in the construction of the Temple, the largest, most probable source was the Chel Maran quarry. It is due to the more similarity of stones used in the Anahita Temple and the samples from this quarry from geochemical point of view as well as the archaeological evidences present in this quarry. The results are also useful for conservators to select appropriate materials for reconstruction of the decayed parts of the Anahita Temple.
\end{abstract}

Keywords: Anahita Temple, Stone quarry, Geochemistry, Limestone, XRF, XRD, Petrography

\section{Introduction}

Stones were the main building material used in the construction of both large and small buildings in the Iranian highlands during the Persian Empire period (6th century $\mathrm{BC}$ to 7 th century $\mathrm{AD}$ ). These include many architectural complexes and archaeological sites such as Persepolis (Thakht-e Djamshid) and Pasargadae, which date from the Achaemenid era [1-4]; Sasanian buildings in the south of Iran such as the Palace of Ardeshir, Firuzabad, Bishapur and Qaleh Dokhtar; Takht-e Soleiman in northern Iran, and Taq-e Gara and Dias of Khosrow Palace in Qasr-e Shirin, etc. in the west of the country [5-10]. The extensive use of stone in the historical architecture of the

\footnotetext{
*Correspondence: o.oudbashi@aui.ac.ir

${ }^{1}$ Department of Conservation of Cultural and Historical Properties, Art University of Isfahan, Isfahan, Iran

Full list of author information is available at the end of the article
}

Iranian highlands was due to the availability of the raw materials (especially limestone and igneous rocks) in the Zagros Mountains, a long range of mountains that starts in northwestern Iran (Azerbaijan) and also covers significant areas of southeastern Turkey and northern Iraq. It then runs south along Iran's western border, until it reaches the coast of the Persian Gulf [11].

Scientific subjects such as stone mining activities and the investigation on provenance of stone raw materials used in ancient constructions have been widely studied around the world and are one of the most important subjects in multidisciplinary investigations in archaeological science [12-14]. Research is normally divided into two different parts. Firstly, the stones used in the construction of the buildings (masonry and large pieces) and secondly, decorative stones, stone tools and gemstones. With the development of advanced archaeological, geological, mineralogical and geochemical techniques for
Springer Open

(c) The Author(s) 2020. This article is licensed under a Creative Commons Attribution 4.0 International License, which permits use, sharing adaptation, distribution and reproduction in any medium or format, as long as you give appropriate credit to the original author(s) and the source, provide a link to the Creative Commons licence, and indicate if changes were made. The images or other third party material in this article are included in the article's Creative Commons licence, unless indicated otherwise in a credit line to the material. If material is not included in the article's Creative Commons licence and your intended use is not permitted by statutory regulation or exceeds the permitted use, you will need to obtain permission directly from the copyright holder. To view a copy of this licence, visit http://creativeco mmons.org/licenses/by/4.0/. The Creative Commons Public Domain Dedication waiver (http://creativecommons.org/publicdomain/ zero/1.0/) applies to the data made available in this article, unless otherwise stated in a credit line to the data. 
the analysis of ancient materials, archaeologists and archaeometrists from around the world started to carry out investigations on the sourcing areas of stones and raw materials used for ancient buildings, especially large, decorative stone blocks [e.g. 15-21]. These studies of the provenance of stone building materials, which have drawn the attention of experts from a range of different disciplines in recent decades, have three main purposes: sourcing stone for the conservation-restoration of ancient and historic buildings [e.g. 22-25], identification of the stones and quarries used in the construction of ancient buildings and monuments [e.g. 26-32] and the characterization of stone types, especially in decorative and gem stones, as a means of tracing trade and regional relations in the ancient world [33-35].

There have however been relatively few studies on ancient stone quarrying and stone working in the Iranian Plateau. These are limited to a few archaeological and archaeometric investigations of specific stone quarries related to important archaeological sites and monuments. These include, for instance, the studies on stone quarries and stone working in Persepolis and Pasargadae, two important Achaemenian world heritage sites in the Fars province (south-central Iran) [1, 3, 36, 37], preliminary studies of stone quarries in western Iran including Hegmataneh [38], Taq-e Bostan [39] and the Chel Maran quarry in Kangavar [40-42] and reviews about stone quarrying in Iran, such as the short review by D. Huff [43]. This shows that despite the fact that stone was the main building material in Iran's ancient monuments, insufficient research has so far been conducted on stone mining archaeology in different periods of Iranian history.

One of the best-known stone monuments in Iran is the Anahita Temple, which is located in the center of the modern city of Kangavar in western Iran (Fig. 1a, b). In this area there is widespread evidence of stone cutting and quarrying which have been linked to the construction of the Anahita Temple [44]. The aim of this paper is to perform analytical studies on the stones used in the construction of the Anahita Temple and different stone quarries in the Kangavar region, near the Anahita Temple, in order to discover which quarry was the main source of stone for the Temple. To this end the stones used in the Temple have been characterized by an analytical procedure which started with the sampling from the monument itself and from the different quarries, followed by microscopic and chemical analyses to characterize the ancient stone. Our results could also be useful in the selection of the most suitable stones for use in the conservation/restoration of the Anahita Temple in the future by using the main stone quarrying area as a resource to select stone pieces for reconstructing decayed parts of the Anahita Temple of Kangavar.

\section{The Anahita Temple of Kangavar}

The Anahita Temple of Kangavar is one of the bestknown archaeological and architectural heritage monuments in Iran and has been studied and excavated for many years. Archaeological excavations of the site were carried out by S. Kambakhshfard (1968-1975) and continued by M. Azarnoush (1977-1978) [10]. Further excavations together with conservation and restoration works were performed by A. Valinoori in 1986 and from 1988 to 2001 by A. Kabiri and M. Mehryar [45]. Archaeological studies in different layers of the excavations have uncovered a great deal of evidence from various periods in the history of Iran (Achaemenid, Parthian and Sasanian Empires up to the Early Islamic era). The findings were dated so confirming that the Temple complex had been used during these four historic periods [46]. It would seem that the complex was constructed in the Achaemenid period as a temple (4th or 5th century BC) and was used during the Parthian and Sasanian periods as either a temple or a palace. Nevertheless, some scholars believe the complex dates from a later era, arguing that it was built as a palace for the Sasanian kings (6th and 7th centuries AD) [43, 47, 48]. After the Muslims entered Iran (about 7th century AD), it fell into disuse, although there is some evidence from the Islamic period of small settlements on the ruins of the Temple [10]. The Anahita Temple also features in the accounts of various early Persian, Arab and western geographers and travelers, such as Ebn-e Khordadbeh, (ca. 870 AD), Estakhri (ca. 940 AD), Hamdollah Mostowfi (ca. 1360 AD) and Isidore of Charax (37 AD). These were followed in more modern times by western travelers such as Robert Ker Porter (1821 AD), Henry Rawlinson (1841 AD) and Marcel Dieulafoy (1884 AD), showing the importance of this complex even after it was dismantled and abandoned [10, 46]. The western geographers and historians described the complex as a Seleucid-Parthian temple, while Isidore of Charax suggested it might be the Temple of the Greek Goddess, Artemis, the equivalent to the Persian Goddess of Anahita in Ancient Persian culture. For their part, the Iranian/Islamic historians and geographers described it as a Sasanian palace for which they noted a range of names: Khosrow's Portico, Parviz's Palace, Qasr-e Shirin and Qasr-e Al-lasus (Al-luslus, Alsus) [10, 43, 45, 46, 49, 50]. Whatever its exact purpose, the fact that it was so often mentioned in ancient texts shows that the Anahita Temple of Kangavar was a very important place during the pre-Islamic Persian Empires from the 6th century BC to the 7th century AD [46]. 


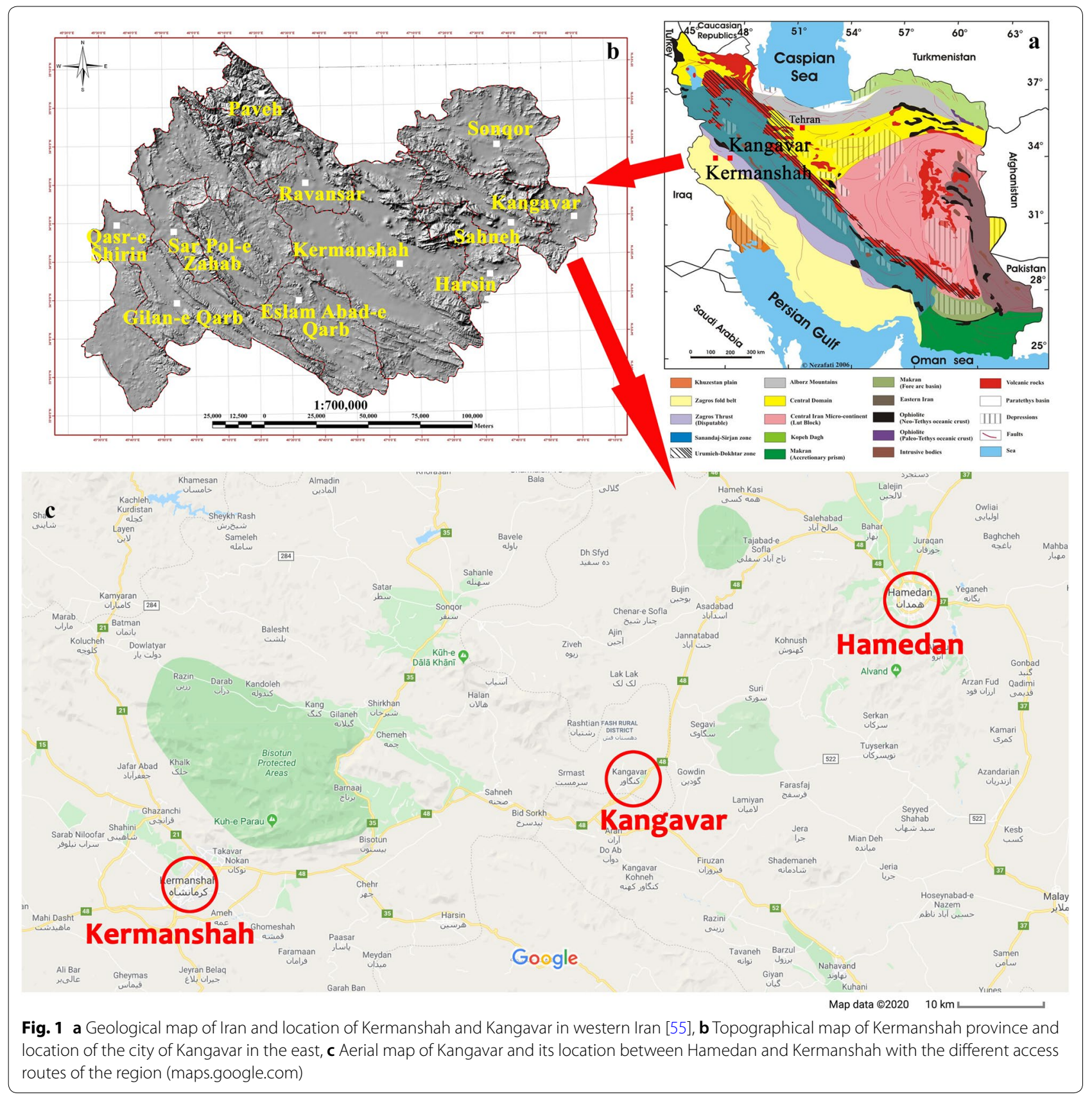

The city of Kangavar is in the center of the eastern county of Kermanshah province and lies west of Hamadan province and the northern part of the Zagros fold and thrust belt (Zagros FTB). Geological surveys indicate that Kermanshah province is located on two well-known geological formations in Iran, namely Sanandaj-Sirjan and Zagros FTB, which are bordered by the active seismic faults of Morvarid and Sahneh. The county and the city of Kangavar are located in the Sanandaj-Sirjan metamorphic belt of the Zagros Mountains (Fig. 1a) [51-54].
The Sanandaj-Sirjan zone was formed in the northern part of the Zagros orogeny and experienced both the Cimmerian and Late Cretaceous orogenies, as well as younger Alpine phases in some areas. Its northern part is composed of low-grade metamorphic rocks from the Mesozoic, which have been intruded by Jurassic to MidTertiary intrusive bodies and granitoids [55]. The Kangavar basin is composed of unconsolidated terrestrial Quaternary sediments that cover Mesozoic and Cenozoic formations. In fact, most of the formations in this basin 
include terrestrial deposits from flood plains composed of intermediate layers of sand and clay and lens-shaped layers of clay of different depths in the various parts of the basin. In some areas, the outcrops of the formations show both dark and light grey, recrystallized argillaceous limestones that are visible in thick-bedded structure. These outcrops are from the Cretaceous age [56, 57].

The Anahita Temple of Kangavar is located in the west of Kangavar city in western Iran, beside the road between Kermanshah and Hamadan (Fig. 1c). The geographical coordinates of this site are $47^{\circ} 57^{\prime} \mathrm{E}$ and $34^{\circ} 30^{\prime}$ $\mathrm{N}$ respectively. The main construction of the archaeological complex is a massive building formed by a large square terrace measuring $209 \mathrm{~m}$ by $224 \mathrm{~m}$, which was constructed around a low, natural rock (hill). The terrace was filled with raw stone pieces and gypsum mortar to create a large, semi-natural/semi-artificial hill-a natural hill that is shaped in rectangular form with stone pieces and gypsum mortar- which was then covered with large, carved stone blocks with smooth surfaces as a façade, above which two other floors were constructed (Fig. 2a, $\mathrm{c}-\mathrm{f})$. The stone blocks forming the surface of the building were joined together using iron clamps, a technique used by the Achaemenids $[3,46]$. According to the virtual reconstructions by Kambakhshfard [10] and Mehryar and Kabiri [45], the building had three floors or levels consisting of a main platform with two terraces built on top (Fig. 2a, b). In the southern part of the building, the remains of a staircase with opposing flights are visible parallel to the façade. A row of thick columns located on the first floor were also uncovered in excavation operations. These columns are short and thick, measuring $3.54 \mathrm{~m}$ in height and $1.44 \mathrm{~m}$ in diameter. Some of the columns are located in their original position on the northwest part of the largest terrace (Fig. 2d, f). Three of them have been restored in recent decades [45].

The construction and position of the two staircases in the Anahita Temple are reminiscent of the Achaemenid staircases in Persepolis and also of Sasanian staircases, such as the one at the Khosrow Palace in Qasr-e Shirin, western Iran $[50,58]$. It is worth noting that the construction of the staircases and the stone walls around the large platform at the Anahita Temple of Kangavar is more rudimentary, less precise than that used in Persepolis and bears closer resemblance to the Khosrow Palace in Qasr-e Shirin [47, 50]. The idea of constructing the Kangavar staircase ramps in the Achaemenid manner is probably an Iranian tradition, although it may have a slight Hellenistic-Roman influence, given the details of the cornice and the pseudo-Roman colonnade [50]. The

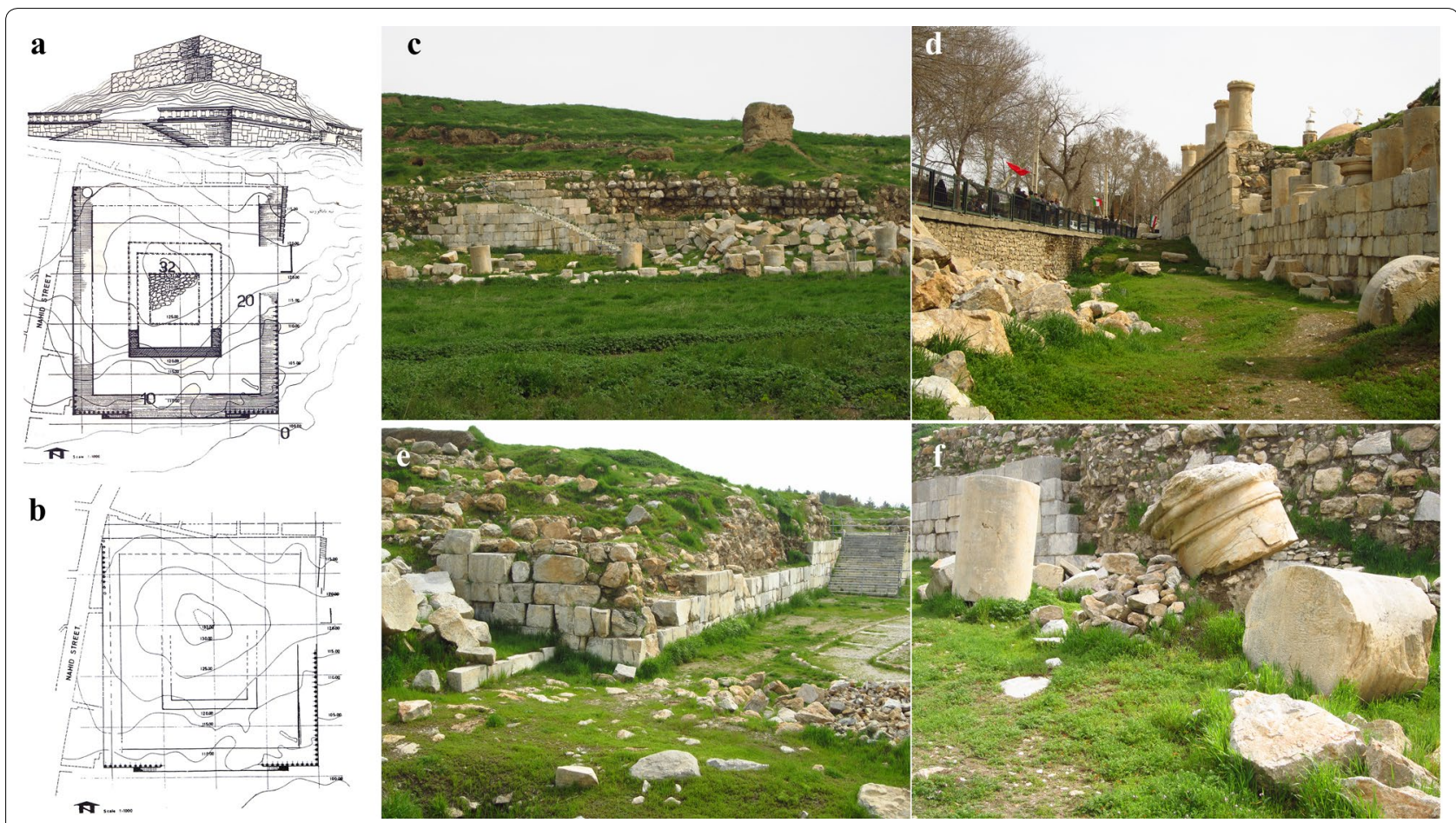

Fig. 2 a Reconstruction of the Anahita Temple of Kangavar [10], b plan of the excavated area of Anahita Temple [10], c view of the main terrace from the south showing the natural hill, the artificial stone and mortar mass and the carved stone blocks used to cover the structure, $\mathbf{d}$ western wall and remains of the huge columns over the wall, e southwestern corner of the main terrace and western part of the southern staircase, $\mathbf{f}$ broken pieces from the huge columns, remains of the western wall and of the large, artificial structure made of stone and mortar 
exact function of the Anahita Temple of Kangavar is not yet clear, although archaeological excavations have been conducted at this site for many years. Archaeologists and historians disagree as to its possible function and date such that it has been variously described as an Achaemenid Palace, a Sasanian Palace and a Seleucid-Parthian temple. Despite this lack of consensus regarding its age and function, this huge building remains one of the most important examples of stone architecture from the Persian Empires of Iranian history.

Although, there are different hypotheses about the archaeology, history and construction of the Anahita Temple of Kangavar [10, 45-48, 50], information about the sources of the raw materials, the carving and preparation of the stones in quarries and the finishing processes are limited to a number of descriptive reports on the stone quarries in this area [41, 44]. Other archaeological and conservation reports have identified one particular area as the stone quarry from which the masonry for the Temple was extracted.

\section{Ancient stone quarries}

Archaeological surveys and in-field documentation indicate that there are various quarries in the Kangavar region from which stone was extracted and worked in ancient times. After extraction the stones were cut and carved into blocks. Unfinished stone blocks can still be seen today. These ancient stone quarries are situated in or around the modern city of Kangavar and include Chel Maran mountain (Chehel Maran, Chelmaran or Shel Maran), Baq-e Melli (National Garden), Allah Daneh, Qureh Jil mountain, Rostam Abad, Sarab-e Dehlor, Helale Ahmar area (Red Crescent area), and the area to the south of the Anahita Temple itself (Fig. 3a, b) [10, 41, $44,45]$.

In-field observations suggest that the very limited evidence of stone cutting in the Helale Ahmar quarry and south of the Temple itself mean that it is unlikely that these stone quarries were used for the Anahita Temple [44]. The nearest stone quarry to the archaeological complex is the Baq-e Melli stone quarry. The most widespread evidence of stone extraction, including some unfinished carved blocks, is in the quarry dug out of the Chel Maran mountain. This stone quarry is located about $3 \mathrm{~km}$ west of the Anahita Temple of Kangavar on the western slope of the Chel Maran mountain. The method used to extract the stone and prepare the blocks in this quarry (and other stone quarries in the Kangavar area) is similar to the method for working the stone used in Achaemenian stone quarries in Fars (southern Iran) [3, 43]. Although there are many areas with evidence of stone quarrying in the Kangavar area, large-scale stone working and cutting is only visible at certain sites such as Chel Maran,

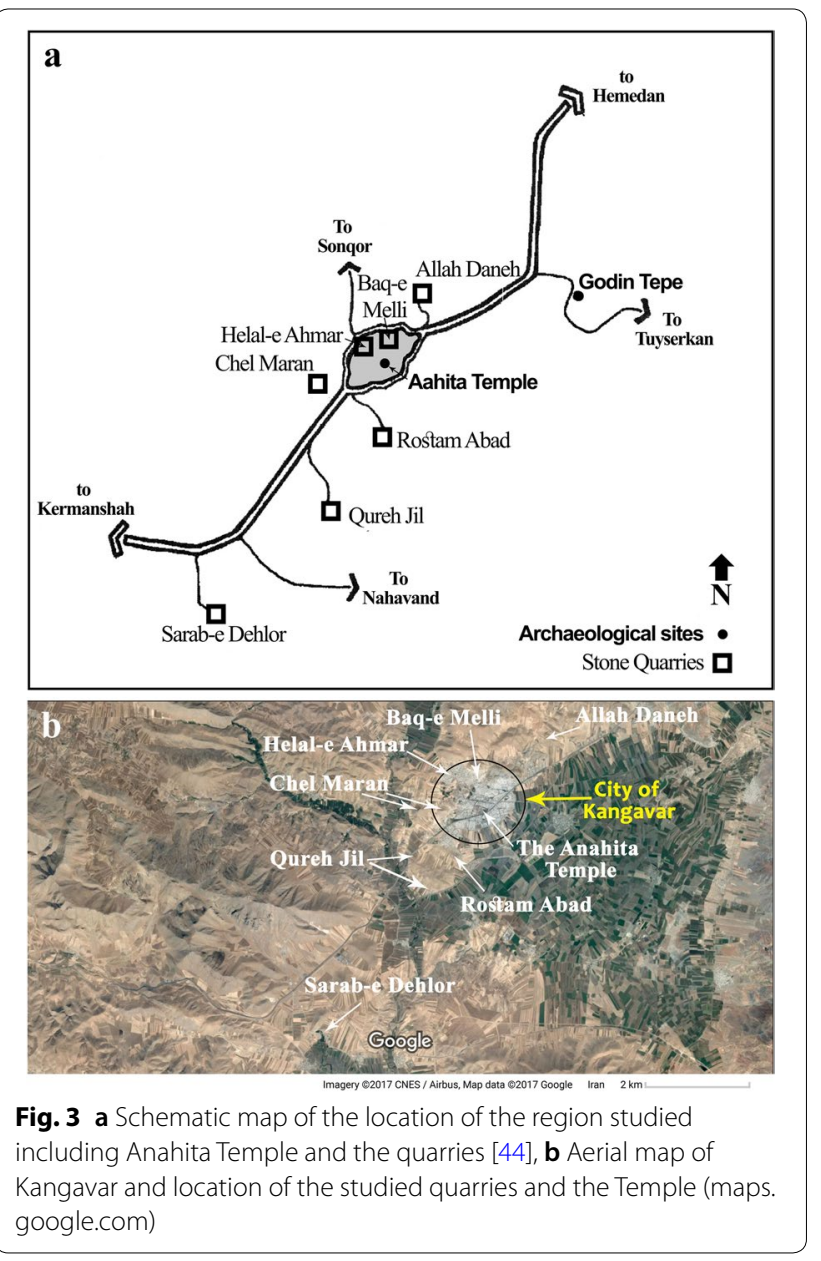

Baq-e Melli and Allah Daneh (Fig. 4). It is therefore very important to find out which stone quarries were used as the main source for the construction of the monument. This was done by conducting a range of different analytical studies as well as by comparing the results of analyses with the archaeological surveys and evidence.

\section{Materials and methods Sampling}

An analytical study was planned and undertaken to investigate the correlation between the stones used at the Anahita Temple and the stone quarries in the Kangavar region. The process was started by collecting stone samples from the Temple and the quarries. These included five samples from stone blocks at the Temple and eight samples from the quarries and stone cutting areas. The stone samples from the Anahita Temple were collected from the stone blocks scattered around the main structure (samples $\mathrm{KN}-1, \mathrm{KN}-2$ and $\mathrm{KN}-3$ ) and from two stone columns from the main building (KN-7 and KN-8). In total, six quarries were sampled and studied in this 
research. The quarry samples were selected from the layers in which stone working and extraction were performed in ancient times (Fig. $4 \mathrm{~d}-\mathrm{h}$ ). Given that in most of the quarries the limestone outcrop used for stone extraction and working was quite small, it was decided to take just one sample from each quarry. In two of the quarries, Chel Maran and Qureh Jil, there was wider evidence of stone working and quarrying and larger exposed outcrops, so two samples were selected from each. On this basis the following samples were taken: two samples from the eastern and western hills of the Chel Maran mountain (CM-1 and CM-2, respectively), two samples from the Qureh Jil mountain (QJ-1 and QJ-2), and one sample each from the Allah Daneh (AD-1), Baq-e Melli (BM-1), Rostam Abad (RA-1) and Sarab-e Dehlor (SD-1) stone cutting areas. The characteristics of the samples are
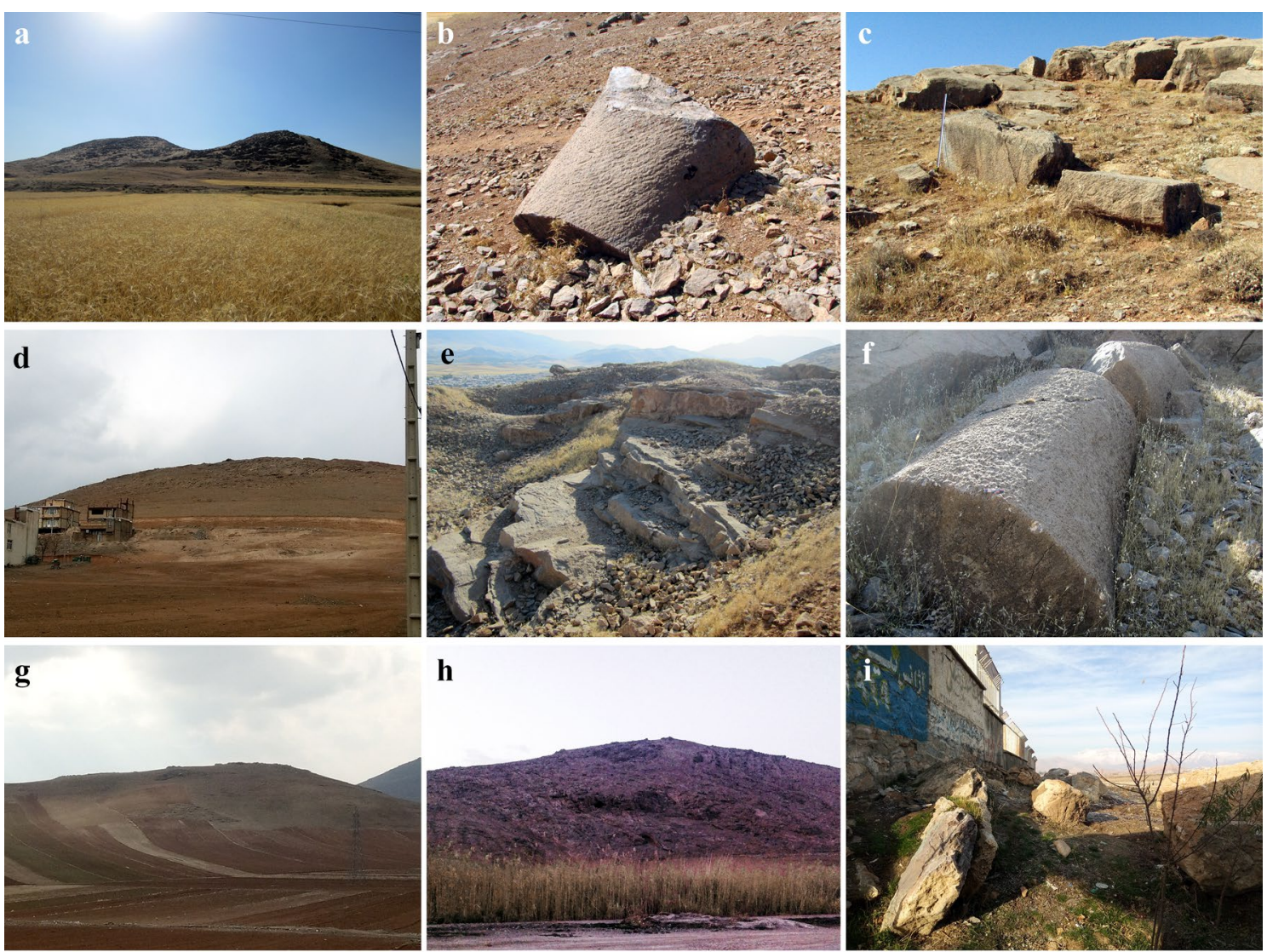

h
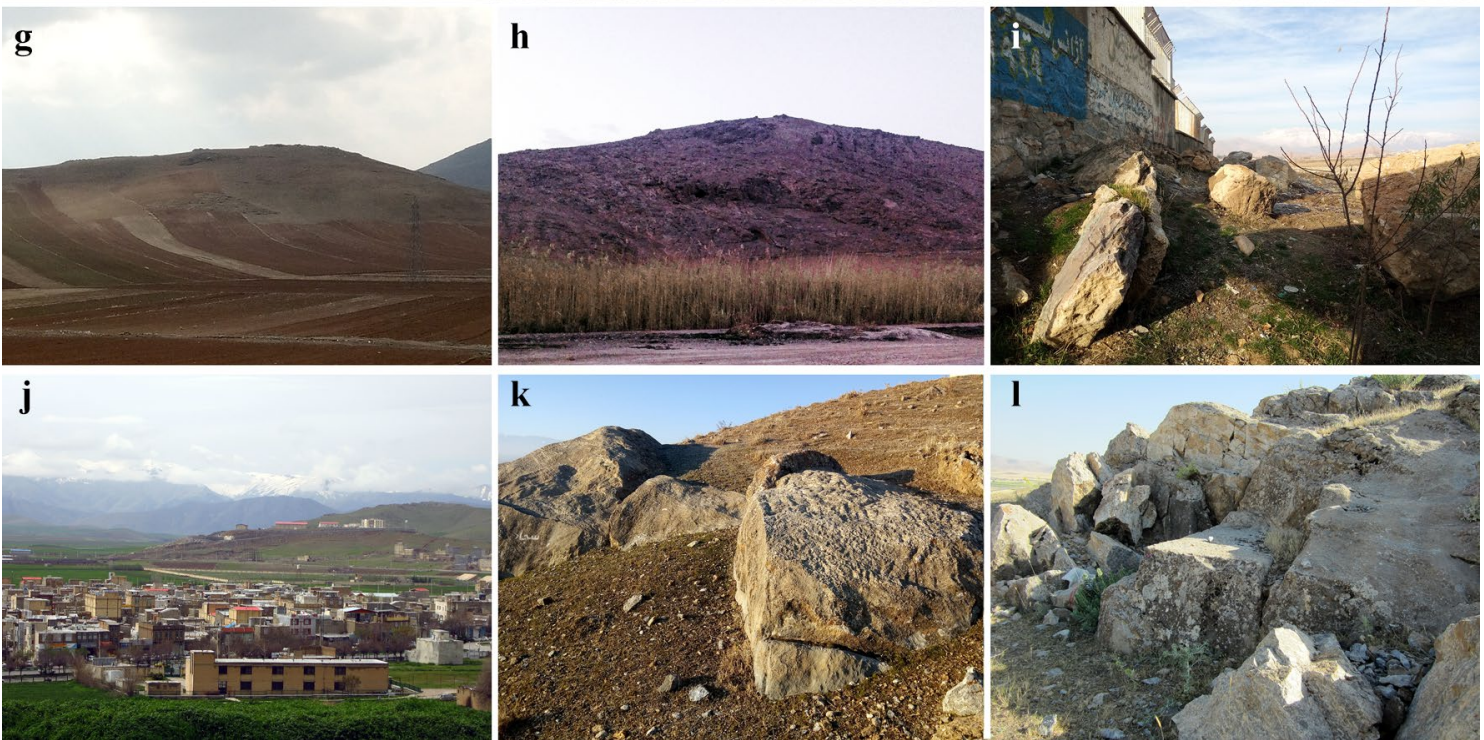

Fig. 4 The stone quarries in the Kangavar region, a view of the Chel Maran mountain from north showing both western and eastern hills, $\mathbf{b}$ an unfinished column in the western hill of the Chel Maran quarry, c carved and unfinished stone blocks in the upper part of the Chel Maran quarry, d an overall view from the Baq-e Melli mountain and the surface stone quarry, e large extractions of stone blocks from the surface of the Baq-e Melli quarry, $\mathbf{f}$ another unfinished column left on the top of the western part of Chel Maran quarry, $\mathbf{g}$ a wide view from the Qureh Jil Mount that its surface is used as a small stone quarry, $\mathbf{h}$ view of Sarab-e Dehlor mount, $\mathbf{i}$ some small evidences of stone extraction in Helal-e Ahmar area located in the central part of the city, $\mathbf{j}$ view of Rostam Abad stone quarry and mountain from the top of the Anahita Temple, $\mathbf{k}$ remains of stone cutting activities in the Rostam Abad quarry including an unfinished column, I another extracted rock in Rostam Abad quarry showing surface quarrying 
presented in Table 1. All samples from the archaeological site and the quarries were used to prepare thin sections and milled to powder for chemical and mineralogical studies.

\section{Analytical studies}

In order to identify the source of the stone used at the Anahita Temple of Kangavar, we decided to use an analytical approach that included microscopic, geochemicalmineralogical and petrographic analyses.

Petrographic characterization was performed on thin sections of the Temple and the quarries using a Primotech model Zeiss transmitted-reflected light microscope. Thin sections were observed under crossed polarized light illumination (XPL). In order to characterize the probable presence of dolomite in the structure of the stone samples, the Alizarin Red S test was performed, after which the thin sections were observed again using the XPL microscope [59].

The X-ray fluorescence technique was used to identify the chemical composition of the samples from the Temple and the quarries. The aim was to characterize the probable relation between the stones from the monument and those from the quarries from a chemical point of view and also provide significant data about the composition of the stone samples. For this purpose, four grams of each powdered sample were pressed into pellet form using boric acid powder as a binder for analysis by X-ray fluorescence (XRF) [60]. XRF analysis of the samples was undertaken to characterize their chemical composition (major, minor and trace constituents). This analysis was performed by a PANalytical PERL'X3 X-ray fluorescence analyser.

Finally, the X-ray diffraction (XRD) method also was used on all samples from the Temple and the quarries to identify the phase composition and the mineralogy of the powdered samples. This method was also used to compare the stone samples from a mineralogical point of view. XRD data were collected on a Philips PW1070 $\mathrm{X}$-ray diffractometer, using a CuK $\alpha \mathrm{X}$-ray source $(\lambda=1.54$ $\AA$ ) with an angular range of between $5^{\circ}$ and $60^{\circ}(2 \theta)$ and $2 \mathrm{~h}$ counting time.

\section{Results and discussion}

The petrographic studies showed that the five samples from the Temple are mainly composed of calcite and have very similar fabric. The microstructure of the samples shows a multi-layered texture including different grain sizes from micrite to sparite (Fig. 5). There are many veins that are filled with secondary calcite with different grain sizes. At higher magnifications, sparitic calcite in xenotopic and hypidiotopic crystal fabric are visible within the micritic layers (Fig. 5). In some parts, peaked low amplitude stylolites along a bedding plane separated laminated fine-grained micrite from sparite. Moreover, there are veins crossed by microstylolites in dark colour, which probably have an accumulation of clay minerals or secondary iron compounds and/or organic matter [59]. The porosity of the samples is very low; some secondary pores are visible due to the removal of the dark phase from the veins, especially in $\mathrm{KN}-2, \mathrm{KN}-7$ and $\mathrm{KN}-8$ (Fig. 5). The presence of crosscutting veins and stylolites are signs of chemical compaction and differential chemical turbulences beside pressure solution by load or tectonic stress during diagenesis in which sediment was transformed into rocks. In fact, these crosscutting veins and fractures may have been formed due to the presence of clay (dark parts) within the calcite during diagenesis, when the stone was subject to high pressure [61]. One important difference between $\mathrm{KN}-1$ and $\mathrm{KN}-2$ and the

Table 1 Characteristics of the stone samples analyzed in this study

\begin{tabular}{|c|c|c|c|}
\hline & Sample code & Type of sample & Place of sampling \\
\hline \multirow[t]{5}{*}{ Temple } & $\mathrm{KN}-1$ & Anahita Temple & Stone block around the main structure \\
\hline & $\mathrm{KN}-2$ & Anahita Temple & Stone block around the main structure \\
\hline & $\mathrm{KN}-3$ & Anahita Temple & Stone block around the main structure \\
\hline & $\mathrm{KN}-7$ & Anahita Temple & Stone Column \\
\hline & $\mathrm{KN}-8$ & Anahita Temple & Stone Column \\
\hline \multirow[t]{8}{*}{ Quarries } & $\mathrm{RA}-1$ & Rostam Abad Quarry & From the stone cutting area \\
\hline & QJ-1 & Qureh Jil Quarry & From the stone cutting area \\
\hline & QJ-2 & Qureh Jil Quarry & From the stone cutting area \\
\hline & CM-1 & Chel Maran Quarry & From the stone cutting area \\
\hline & $\mathrm{CM}-2$ & Chel Maran Quarry & From the stone cutting area \\
\hline & AD-1 & Allah Daneh Quarry & From the stone cutting area \\
\hline & $\mathrm{BM}-1$ & Baq-e Malli Quarry & From the stone cutting area \\
\hline & SD-1 & Sarab-e Dehlor Quarry & From the stone cutting area \\
\hline
\end{tabular}



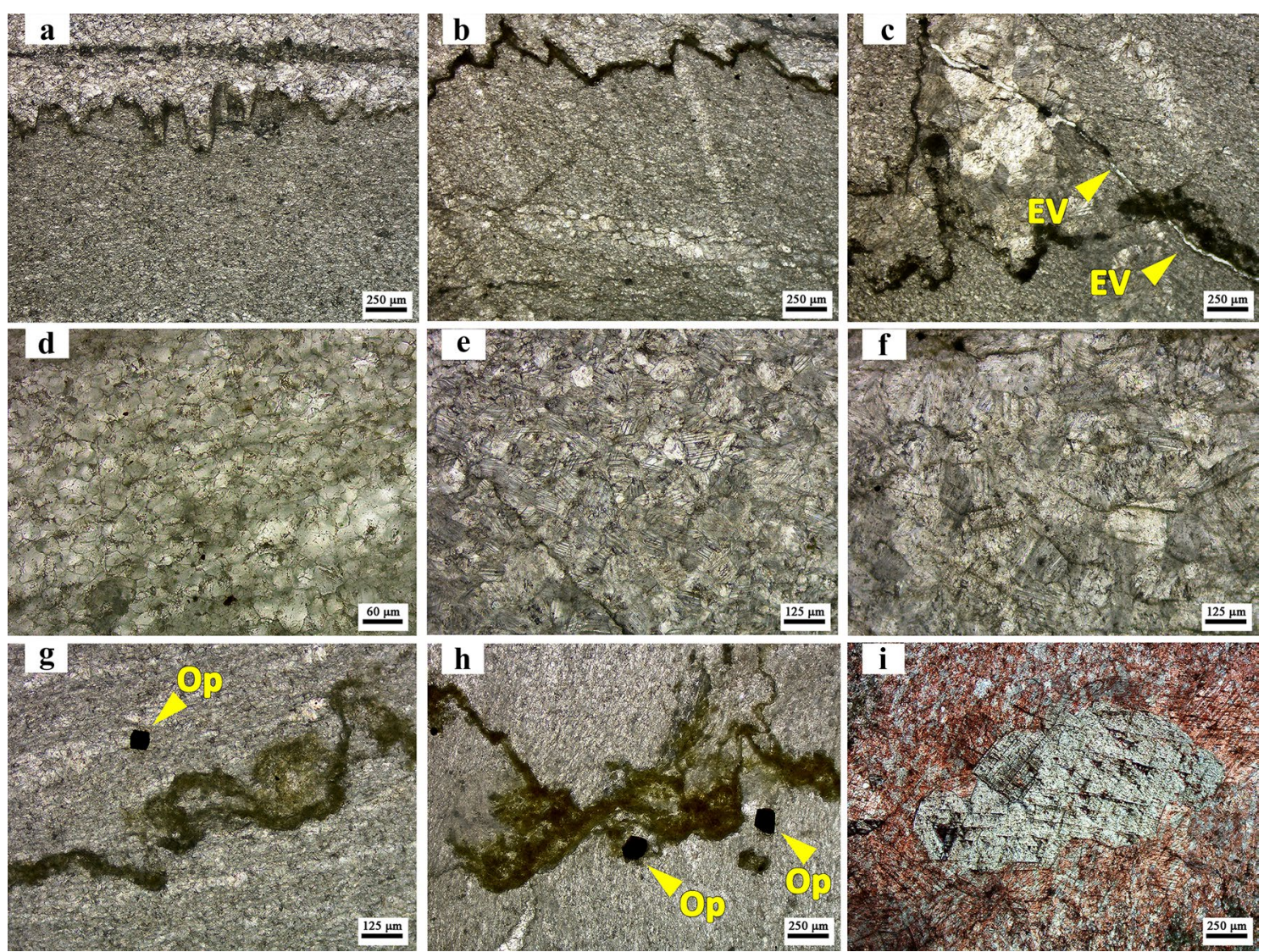

Fig. 5 Petrographic images of samples from the Temple: a multi-layer fabric of sample KN-1 including micrite to sparite; $\mathbf{b}$ multi-layer fabric of KN-7 in which the crosscutting veins are brighter in the micrite matrix; c crosscutting veins and stylolite in sample KN-8. Yellow arrows show an empty vein (secondary porosity); $\mathbf{d}$ detail of hypidiotopic calcite crystals from KN-8; e detail of micro-sparite texture from $\mathrm{KN}-3$, which shows the hypidiotopic calcite crystals; $\mathbf{f}$ detail of hypidiotopic sparite from KN-2; $\mathbf{g}$ detail of stylolite and cubic opaque crystals from KN-2 (yellow arrow); $\mathbf{h}$ arrows show the opaque cubic crystals in the fabric of KN-1; i Alizarin Red S staining test indicates idiotopic rhombohedral crystals of dolomite in the fabric of KN-1

other samples from the Temple is that they include cubic crystals which are black in transmitted light (Fig. 5) and opaque in reflected light that is probably hematite (iron oxide) or other iron compounds such as pyrite (iron sulphide). Furthermore, the Alizarin Red S staining test revealed the presence of idiotopic crystals of dolomite within the micritic texture in one sample (KN-1) (Fig. 5i), while sporadic dolomite crystals were observed around the sparite veins and stylolites in $\mathrm{KN}-3$ and $\mathrm{KN}-8$.

The microstructures of the samples from the quarries vary in terms of fabric, although they have similar constituents, including micritic to sparitic calcite grains. Other features include veins of varying size filled with sparitic secondary calcite and some stylolites, probably filled with dark phases of clay and secondary Fe-rich phases (Fig. 6). All samples have very low porosity, although some holes and pores have appeared due to the disappearance of clays and iron phases from the veins and pores leading to an increase in the secondary porosity (e.g. samples CM-1, AD-1 or QJ-2). Nevertheless, we were able to rule out some of the possible quarries due to differences in the morphology and size ranges: for example, the size of the secondary veins filled with calcite and clay varies from large to very small in samples RA-1, BM-1, QJ-2 and AD-1, which indicated a different fabric (Fig. 6). Another different feature in some samples, in particular QJ-1, was the presence of microfissures filled with dark phases due to high pressure during diagenesis beside rhombohedral dolomite crystals in the fabric of the stone. The most important difference was the presence of bioclasts in QJ-1, SD-1 and CM-1 (Fig. 6b-d). The stone sample from Sarab-e Dehlor (SD-1) had another characteristic distinguishing feature, namely microfossils in significant amounts. These can be categorized as bio-micrite fabric, which suggests that SD-1 is quite different from the other samples. The Alizarin Red $S$ test showed that dolomite is widespread in the calcitic matrix of all the 

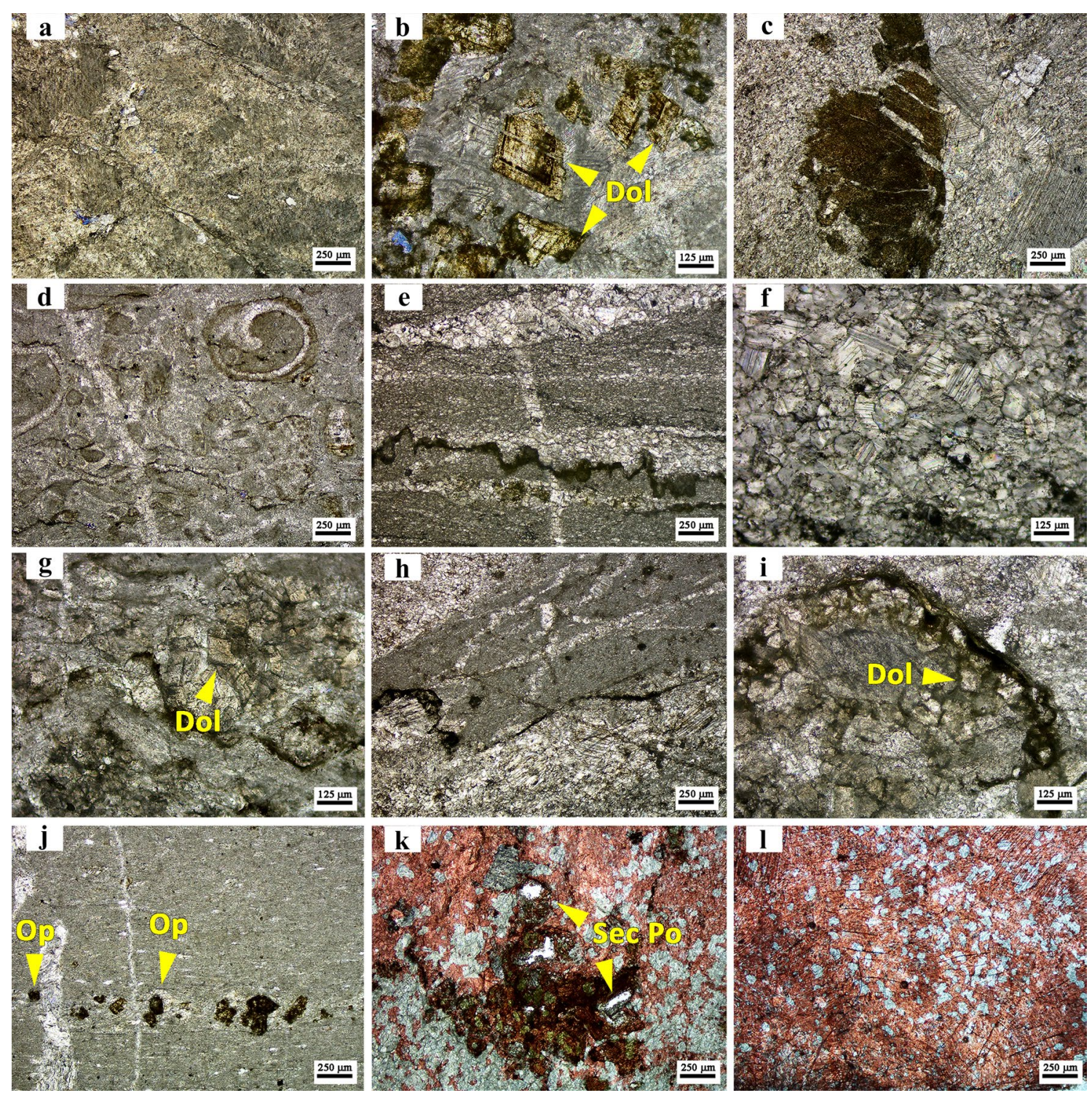

Fig. 6 Petrographic images of the samples from the quarries, a micrite to sparite fabric of sample RA-1 that shows a microfissure and fine stylolite due to diagnosis pressure; $\mathbf{b}$ sparite fabric from QJ-1 including rhombohedral crystals of dolomite (marked with arrows); c sparite crystals from CM-1 including bioclast filled with secondary phase (clay or iron component); $\mathbf{d}$ bioclast fabric of SD-1; e multi-layer fabric from micrite to sparite from CM-1 including stylolites; $\mathbf{f}$ detail of hypidiotopic sparite crystals from CM-1; $\mathbf{g}$ yellow arrow indicates rhombohedral crystals of dolomite from BM-1 scattered within the micrite to sparite fabric; $\mathbf{h}$ crosscutting of veins filled with sparitic calcite beside stylolites in sample AD-1;i detail of AD-1 fabric indicates rhombohedral dolomite crystals beside the vein (yellow arrow); j dark crystals within the micrite fabric of QJ-2, yellow arrow indicates two probable opaque cubic crystals; $\mathbf{k}$ Alizarin Red S staining of $\mathrm{CM}-1$ indicates the wide presence of dolomite crystals, arrows indicate secondary porosities; I widespread dolomite crystals within the fabric of RA-1 after Alizarin Red S staining

samples from the quarries, except for CM-2 and AD-1, which include sporadic dolomite crystals, although the amount and the size of the dolomite grains vary greatly from one sample to the next (Fig. $6 \mathrm{k}-\mathrm{l}$ ). We also noticed the presence of cubic-shaped opaque crystals in just one sample QJ-2, which shows a correlation with the $\mathrm{KN}-1$ and $\mathrm{KN}-2$ samples from the Temple.
The petrographic study of thin sections of stones from the Anahita Temple showed a layered fabric of micrite to sparite in all samples. There were many veins of secondary calcite in the texture of the samples. Furthermore, some compact dark veins, presumably composed of clays, were visible in the microstructure. The Alizarin Red S test indicated some sporadic dolomite crystals in 
the texture of the stone samples. The petrographic study comparing the microstructure of the stones from the Temple and the quarries shows that the Qureh Jil (QJ1), Sarab-e Dehlor and Baq-e Melli have fewer similarities with the fabric of the stones used in the Temple. The sample with least similarities is the one from the Sarab-e Dehlor quarry. The stone texture of samples QJ-2, RA-1, AD- 1 and CM-1 is closer to that of the Temple stones, although they have a higher quantity of dolomite. In fact, QJ-2 has a similar fabric to the samples from the Temple because of the micritic matrix, the sparitic veins and the cubic opaque crystals, which are probably filled with iron compounds such as pyrite. However, the greatest similarity between the fabric of the samples from the quarries and those from the Temple was in CM-2, due to the small amount of dolomite, the layered micrite to hypidiotopic sparite and the similar morphology of the stytolites and the veins filled with secondary calcite and clay minerals probably such as illite or muscovite.

$\mathrm{XRD}$ analysis of the stone from the Anahita Temple also showed that calcite $\left(\mathrm{CaCO}_{3}\right)$ is the main phase detected in all the samples (Table 2, Fig. 7). Quartz $\left(\mathrm{SiO}_{2}\right)$ was detected as the minor phase in all five samples of the Temple, while dolomite $\left(\mathrm{CaMg}\left(\mathrm{CO}_{3}\right)_{2}\right)$ was detected in sample $\mathrm{KN}-1$ and gypsum $\left(\mathrm{CaSO}_{4} \cdot 2 \mathrm{H}_{2} \mathrm{O}\right)$ was detected in samples $\mathrm{KN}-7$ and $\mathrm{KN}-8$. The analysis of the stone samples from the quarries revealed that, like the samples from the Temple, calcite is the major phase in the composition of almost all the stones (Table 2, Fig. 7). The exception was BM-1 in which dolomite was identified as a major phase alongside calcite. Quartz was identified as a minor phase in the stone from all the quarries, although it is detected in samples QJ-1

Table 2 Results of XRD analysis of the stone samples from the Anahita Temple and the stone quarries

\begin{tabular}{llll}
\hline & Sample & Major phase & Minor phase \\
\hline Temple & KN-1 & Calcite & Quartz; dolomite \\
& KN-2 & Calcite & Quartz \\
KN-3 & Calcite & Quartz \\
KN-7 & Calcite & Quartz; gypsum \\
KN-8 & Calcite & Quartz; gypsum \\
Quarries & RA-1 & Calcite & Quartz \\
QJ-1 & Calcite & Quartz \\
QJ-2 & Calcite & Quartz \\
CM-1 & Calcite & Quartz; dolomite; Illite (mus- \\
& & covite) \\
CM-2 & Calcite & Quartz \\
AD-1 & Calcite & Quartz; dolomite; lllite (mus- \\
& & covite) \\
BM-1 & Calcite; dolomite & Quartz; llite (muscovite) \\
SD-1 & Calcite & Quartz; dolomite \\
\hline
\end{tabular}

and BM-1 in significant content. Also, dolomite and illite/ muscovite were detected as minor phases in three samples. In general, the phase composition of the samples from the Temple resembles those from quarries such as Rostam Abad (RA-1), Qureh Jil (QJ-1 and QJ-2) Chel Maran (CM2) and Sarab-e Dehlor (sample SD-1).

Table 3 shows the results of XRF analysis of major and minor elements in the stone samples. The results revealed that the main component of all the samples (Temple and quarries) is $\mathrm{CaO}$, whose content varies from 39.23 to 54.95 $\mathrm{wt} \%$. The second most important component was $\mathrm{SiO}_{2}$. The amount of $\mathrm{SiO}_{2}$ has been measured 7.5 and $10.76 \mathrm{wt} \%$ in samples QJ-1 and BM-1, respectively. It shows that why quartz is detected as minor phase with significant content in the composition of both samples. Instead, $\mathrm{MgO}$ was an important constituent of just two samples (AD-1 and $\mathrm{BM}-1$ ) and the $\mathrm{Al}_{2} \mathrm{O}_{3}$ content of the sample from the Sarabe Dehlor quarry was more than one percent. Other constituents with less than $1 \%$ content were considered minor components. The results of XRF analysis show that the stone samples from the Temple and the quarries are carbonate stones (calcareous) due to their high $\mathrm{CaO}$ content $[62,63]$. Perhaps the most important differences between the stones we analyzed is the presence of significant amounts of $\mathrm{MgO}$ and $\mathrm{SiO}_{2}$ in some of the samples. Figure 8 shows the ternary diagram for $\mathrm{CaO}-\mathrm{SiO}_{2}-\mathrm{MgO}$ in the composition of the analyzed stones. This diagram shows that all the stones are rich in $\mathrm{CaO}$ and that the composition of the samples from quarries such as Rostam Abad (RA$1)$ and Chel Maran (CM-2) was very similar to that of the samples from the Temple. The samples from Qureh Jil (QJ1) and Sarab-e Dehlor have less in common with the samples from the Temple in terms of their main composition.

Table 4 shows the trace elements identified in the composition of stone samples from the Temple and the quarries (measured in $\mathrm{ppm}$ ). $\mathrm{Sr}, \mathrm{Zr}, \mathrm{Cr}, \mathrm{Ba}$ and $\mathrm{Pb}$ were all detected in significant amounts while other trace elements had much lower content. Also it is worth noting that the composition of the samples is very similar based on many of REE elements. The analysis of the correlation between the trace elements and the minor constituents in the composition of carbonate stones is a useful way of studying the provenance of these type of stones $[64,65]$. Figure $9 \mathrm{a}-\mathrm{c}$ shows scatter plots for $\mathrm{Fe}_{2} \mathrm{O}_{3}, \mathrm{Al}_{2} \mathrm{O}_{3}$ and $\mathrm{Na}_{2} \mathrm{O}$ versus $\mathrm{Sr}$ in the composition of the stone samples. The diagrams show that the stone samples from the Temple have a very close correlation with two samples from the Chel Maran (especially CM-2) and Qureh Jil (QJ-1 and QJ-2 samples) quarries. Some samples from Allah Daneh and Sarab-e Dehlor also have considerable correlation with samples from the Temple. The scatter plot for $\mathrm{Fe}_{2} \mathrm{O}_{3}, \mathrm{Al}_{2} \mathrm{O}_{3}$ and $\mathrm{Na}_{2} \mathrm{O}$ versus $\mathrm{Zr}$ in the composition of the stone samples can be seen in Fig. $9 d-f$. It is clear from these scatter plots that the 

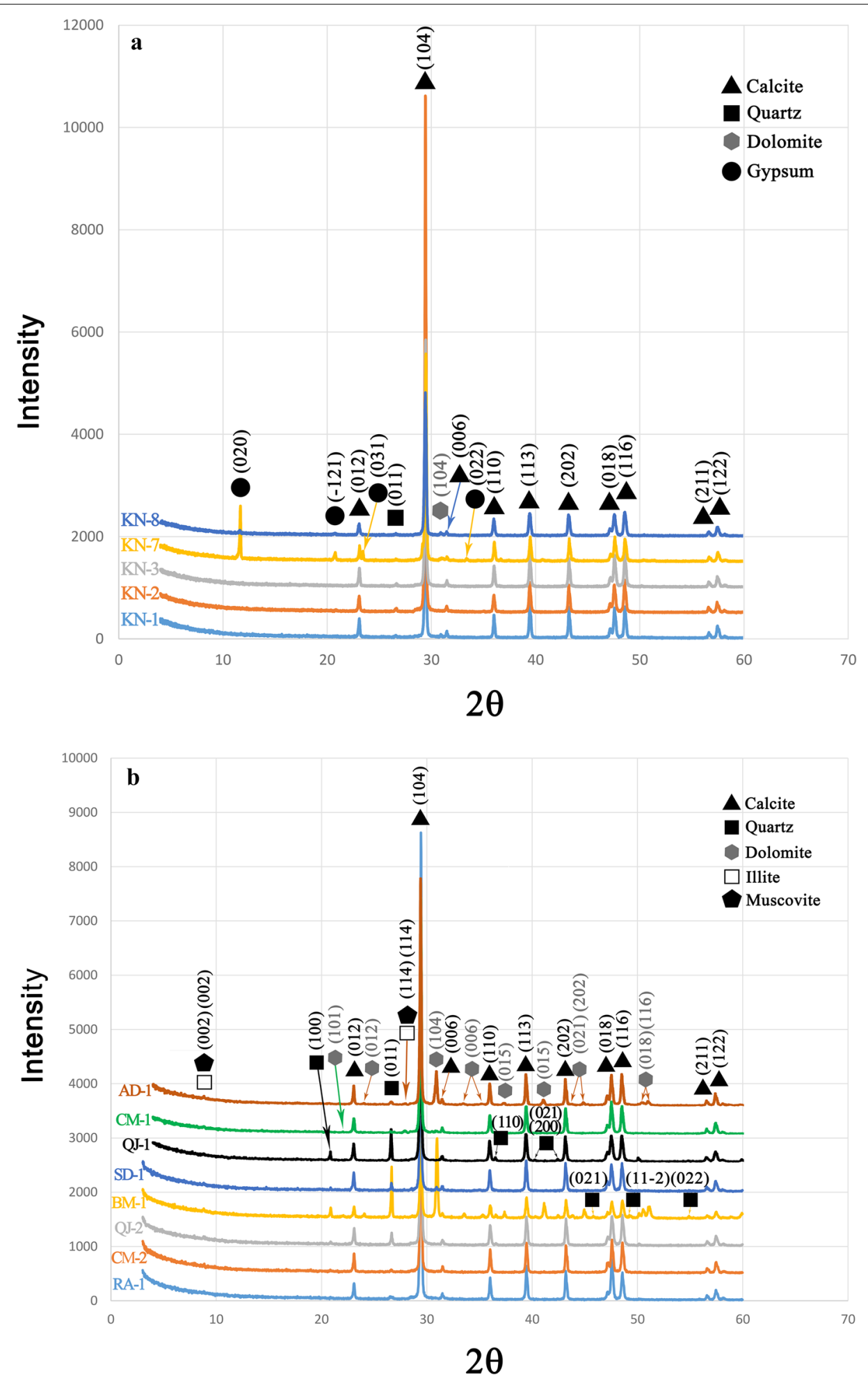

Fig. 7 a X-ray diffractogram of five stone samples from the Anahita Temple. Calcite is the main phase, while the minor phases are quartz and dolomite. Gypsum is the minor phase in two samples (KN-7 and KN-8). $\mathbf{b}$ X-ray diffractogram of eight samples from the stone quarries. Calcite is detected as the main phase in all the samples. In sample BM-1 dolomite is also an important phase. Quartz is detected in two samples in significant content. Quartz, dolomite and illite/muscovite are the minor phases in other samples 
Table 3 Results of XRF analysis of the major and minor constituents (oxides, wt \%) of the stone samples from the Anahita Temple and the quarries

\begin{tabular}{|c|c|c|c|c|c|c|c|c|c|c|c|c|c|}
\hline & Sample & $\mathrm{SiO}_{2}$ & $\mathrm{Al}_{2} \mathrm{O}_{3}$ & $\mathrm{Fe}_{2} \mathrm{O}_{3}$ & $\mathrm{MnO}$ & $\mathrm{MgO}$ & $\mathrm{CaO}$ & $\mathrm{Na}_{2} \mathrm{O}$ & $\mathrm{K}_{2} \mathrm{O}$ & $\mathrm{TiO}_{2}$ & $\mathrm{P}_{2} \mathrm{O}_{5}$ & LOI & Sum \\
\hline \multirow[t]{5}{*}{ Temple } & $\mathrm{KN}-1$ & 1.07 & 0.59 & 0.17 & 0.01 & 0.77 & 54.49 & 0.06 & 0.11 & - & 0.02 & 42.45 & 99.74 \\
\hline & $\mathrm{KN}-2$ & 1.47 & 0.62 & 0.21 & 0.01 & 0.41 & 54.22 & 0.04 & 0.1 & - & 0.02 & 42.72 & 99.82 \\
\hline & $\mathrm{KN}-3$ & 0.89 & 0.17 & 0.11 & 0.01 & 0.49 & 54.95 & 0.05 & 0.03 & - & 0.02 & 43.12 & 99.84 \\
\hline & $\mathrm{KN}-7$ & 1.37 & 0.62 & 0.18 & 0.01 & 0.8 & 54.91 & 0.19 & 0.09 & 0.02 & 0.03 & 41.12 & 99.34 \\
\hline & $\mathrm{KN}-8$ & 1.31 & 0.49 & 0.18 & 0.01 & 0.74 & 53.56 & 0.07 & 0.09 & 0.02 & 0.02 & 42.74 & 99.23 \\
\hline \multirow[t]{8}{*}{ Quarries } & RA-1 & 1.38 & 0.66 & 0.31 & 0.01 & 0.45 & 53.87 & 0.14 & 0.15 & - & 0.03 & 42.85 & 99.85 \\
\hline & QJ-1 & 7.5 & 0.42 & 0.4 & 0.02 & 0.49 & 50.85 & 0.02 & 0.11 & - & 0.03 & 40.03 & 99.87 \\
\hline & QJ-2 & 3.97 & 0.76 & 0.43 & 0.02 & 0.41 & 52.47 & 0.05 & 0.17 & - & 0.01 & 41.59 & 99.88 \\
\hline & $\mathrm{CM}-1$ & 1.33 & 0.57 & 0.14 & 0.01 & 0.72 & 54.09 & 0.11 & 0.09 & - & 0.02 & 42.78 & 99.86 \\
\hline & $\mathrm{CM}-2$ & 1.43 & 0.41 & 0.14 & 0.01 & 0.56 & 54.39 & 0.03 & 0.08 & - & 0.01 & 42.85 & 99.91 \\
\hline & AD-1 & 1.45 & 0.69 & 0.32 & 0.05 & 3.64 & 50.47 & 0.01 & 0.17 & - & 0.02 & 43.06 & 99.88 \\
\hline & BM-1 & 10.76 & 0.83 & 0.54 & 0.03 & 8.34 & 39.23 & - & 0.18 & 0.01 & 0.06 & 39.64 & 99.62 \\
\hline & SD-1 & 3.53 & 1.35 & 0.59 & 0.04 & 0.76 & 51.61 & 0.07 & 0.28 & 0.04 & 0.02 & 41.48 & 99.77 \\
\hline
\end{tabular}

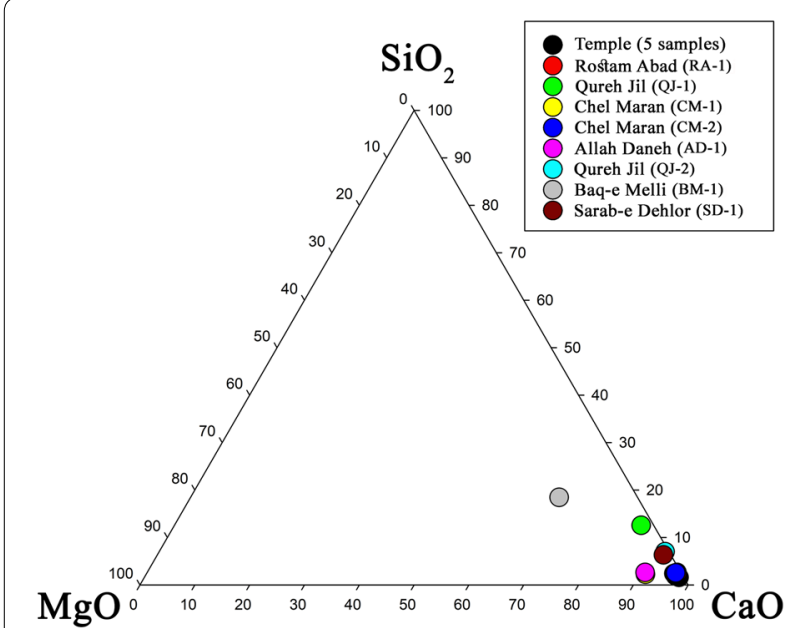

Fig. 8 Ternary diagram for $\mathrm{CaO}-\mathrm{SiO}_{2}-\mathrm{MgO}$ in the composition of the analyzed stones from the Temple and the quarries based on XRF results

samples from the Temple are closely correlated with those from the Chel Maran (especially sample CM-2), Qureh Jil (samples QJ-1 and QJ-2), Allah Daneh (sample AD-1) and Rostam Abad (RA-1) quarries, respectively.

Nevertheless, on the basis of chemical and phase analyses, all the samples from the Temple and the quarries can be categorized as either limestone or dolomitic limestone. There are different methods for classifying carbonate stones which can be used to identify a particular type of limestone in petrological studies. Cox et al. [66] suggested a classification method for carbonate stones based on the percentage of $\mathrm{CaO}$ in their chemical composition. According to this classification, carbonate stones with more than $55.2 \% \mathrm{CaO}$ content contain more than $98.5 \%$ of $\mathrm{CaCO}_{3}$ and can therefore be considered as "very high purity" limestone (method I). The next level of purity is "high purity", for stones with a $\mathrm{CaO}$ content of between 54.3 and $55.2 \%$, in which the amount of $\mathrm{CaCO}_{3}$ will be between 97 and $98.5 \%$. Another method is based on the $\mathrm{MgO}$ content of carbonate stones (method II) [67]. Some early publications about the composition of carbonate stones classified them according to their $\mathrm{CaO} / \mathrm{MgO}$ ratio (method III) [63, 68, 69]. Previous researchers have also proposed different classifications based on the quantity of calcite, dolomite and other insoluble constituents (quartz, clay minerals, etc.) present in the composition of carbonate stones (method IV) [62, 70, 71]. In our case, the XRD analysis showed that minerals such as quartz, dolomite, illite/muscovite and gypsum are present in the composition of samples as impurities.

Based on the analytical results for the stone samples from the Anahita Temple and the quarries, we used the four classification methods described above (methods I, II, III and IV respectively) to identify the different types of carbonate stones analysed. The results are set out in Table 5. According to Classification Method I, the stones used in the Temple can be classified as highpurity and medium-purity limestones. In particular, the sample from Chel Maran 2 (CM-2) is high purity, the samples from Chel Maran $1(\mathrm{CM}-1)$ and Qureh Jil 2 (QJ-2) are medium purity, Qureh Jil 1, Allah Daneh and Sarab-e Dehlor are low purity and the sample from Baq-e Melli is classified as impure limestone. According to Classification Method II all the analyzed samples can be categorized as dolomitic limestone except for those from Allah Daneh (AD-1) and Baq-e Melli (BM-1). These are classified as slightly dolomitic limestones and 
Table 4 Results of XRF analysis of trace elements (ppm) in the stone samples from the Anahita Temple and the quarries

\begin{tabular}{clccccccccccccccccccccc}
\hline & Sample & $\mathbf{V}$ & $\mathbf{C r}$ & $\mathbf{C o}$ & $\mathbf{N i}$ & $\mathbf{C u}$ & $\mathbf{Z n}$ & $\mathbf{G a}$ & $\mathbf{B a}$ & $\mathbf{A s}$ & $\mathbf{C d}$ & $\mathbf{M o}$ & $\mathbf{N b}$ & $\mathbf{P b}$ & $\mathbf{R b}$ & $\mathbf{S b}$ & $\mathbf{S r}$ & $\mathbf{T h}$ & $\mathbf{U}$ & $\mathbf{Y}$ & $\mathbf{Z r}$ \\
\hline \multirow{5}{*}{ Temple } & KN-1 & - & 10.8 & - & 3.6 & 1.7 & 16.4 & 1.8 & 34.2 & 2.5 & 1.6 & 1.1 & 2.1 & 1.7 & 5.4 & - & 147.2 & - & - & 1.5 & 18.8 \\
& $\mathrm{KN}-2$ & 2.2 & 8.5 & - & 5.6 & 7.2 & 15.9 & 2.8 & 38.2 & 2.7 & 1.7 & 1 & 2.5 & 3.5 & 5.6 & - & 177.8 & - & - & 2.7 & 19.1 \\
& $\mathrm{KN}-3$ & - & 8.5 & - & 3.4 & 0.6 & 13.7 & 1.5 & 31 & 2.4 & 1.7 & 0.8 & 2.1 & 2.1 & 2.6 & - & 159 & - & - & 1.2 & 15.8 \\
& $\mathrm{KN}-7$ & - & - & - & - & - & - & - & - & - & - & - & - & 16 & 15 & - & 249 & - & - & 12 & 11.3 \\
& KN-8 & - & 1 & - & - & - & - & - & - & - & - & - & - & 18 & 7 & - & 212 & - & - & 11 & 14.2 \\
Quarries & RA-1 & - & 9.7 & - & 5.5 & 2.3 & 21.1 & 1.8 & 58.9 & 4.7 & 1.7 & 1.2 & 4.8 & 2.8 & 5.8 & - & 477.6 & - & - & 2.7 & 9.7 \\
& QJ-1 & - & 14.3 & - & 10.1 & 2.6 & 21.4 & 1.8 & 35.4 & 10.2 & 1.6 & 1.3 & 3.4 & 18.1 & 4.9 & - & 246.4 & - & - & 4.4 & 17.6 \\
& CM-1 & - & 8.7 & - & 4.3 & 3.3 & 12.1 & 1.8 & 37.2 & 2 & 1.7 & 0.5 & 3.4 & 2.4 & 4.3 & - & 360.9 & - & - & 0.9 & 12.3 \\
& CM-2 & - & 7 & - & 4.9 & 2.8 & 15.3 & 1.6 & 31.9 & 1.2 & 1.7 & 0.9 & 1.8 & 4.3 & 4.7 & - & 140.3 & - & - & 0.4 & 18.3 \\
& AD-1 & 16.2 & 9.5 & - & 6.4 & 0.9 & 17.1 & 1.8 & 39.7 & 4.4 & 1.5 & 1.1 & 2.4 & 3.7 & 6.0 & 0.2 & 214.9 & 0.1 & 2.1 & 2.7 & 18.5 \\
& QJ-2 & 7 & 9.5 & - & 5.2 & 3.1 & 13.1 & 2.5 & 37.4 & 4.6 & 1.6 & 1.2 & 2.9 & 2.8 & 6.6 & - & 177.8 & - & - & 5.5 & 21.2 \\
& BM-1 & 2.5 & 14.5 & - & 8.3 & - & 38.3 & 1.6 & 38.3 & 3.5 & 1 & 1.2 & 2.2 & 5.9 & 6.5 & - & 91 & 0.5 & 0.4 & 6.5 & 32.5 \\
& SD-1 & 6.5 & 9.8 & - & 5.8 & 2.7 & 106.2 & 1.9 & 62.9 & 9.7 & 1.7 & 1.6 & 1.9 & 10.9 & 7.5 & 0.4 & 97 & 0.1 & 0.3 & 1.1 & 29.7 \\
\hline
\end{tabular}

dolomitic limestones sensu stricto, respectively. This is due to the high concentration of $\mathrm{MgO}$ in the stone from these two quarries. According to Classification Method III, all the samples are limestone, although samples AD-1 and BM-1 are slightly dolomitic limestone and dolomitic limestone respectively. Finally, Method IV classifies all the samples from the Temple and the quarries as limestone, except for AD-1 and BM-1, which are classified as dolomitic limestone and impure dolomitic limestone respectively. In general, these comparisons show that the stones used in the Temple are very similar, while the samples from the quarries can vary in terms of composition. In fact, some of the stones from the quarries show low purity based on $\mathrm{CaCO}_{3}$ content (QJ-1, AD-1 and BM-1). Nevertheless, according to Classification Methods II, III and IV the samples from the Temple and the quarries have very similar compositions, while the stones from Allah Daneh and Baq-e Melli are slightly different.

The analytical studies proved that the stone blocks from the Anahita Temple were made out of calcareous stone with some dolomite content as well as very small amounts of impurities such as quartz and clay minerals.

The next stage was to compare the petrographic micrographs for the samples from the Anahita Temple and the quarries. These reveal that the samples from Chel Maran are very similar from a textural point of view, and in particular sample CM-2, which comes from the western part of the Chel Maran mountain, where widespread evidence of quarrying and stone extraction is visible. Based on the classification of the carbonate stones set out in Table 5, it would seem that the stone used in this monument was either limestone or dolomitic limestone. This type of limestone has a fine texture from micritic to sparitic microstructure in which veins of different thickness filled by secondary calcite are visible. A lot of fine veins of iron compounds and clay minerals can also be observed in the fabric of the stones from the Anahita Temple. The results of the analysis of the stone samples from different areas in the Kangavar region in which there was evidence of ancient stone quarrying suggest that some of these quarries were used extensively as a source of raw materials for the construction of the Temple. These materials can be identified as calcareous stones with different impurities. In fact, the stones from the quarries can be classified as either limestone or dolomitic limestone with different impurities (Rostam Abad, Qureh Jil, Chel Maran and Sarab-e Dehlor), with small amounts of dolomite (Baq-e Melli) and as dolomitic and impure dolomitic limestone with large amounts of dolomite (Allah Daneh). Quartz and clay minerals are also present in the composition and texture of the stones from the quarries. It is worth noting that the stone samples from Chel Maran, Qureh Jil and Rostam Abad show a significant correlation with the stones from the Anahita Temple, while the stones from Allah Daneh, Baq-e Melli and Sarab-e Dehlor are less closely related. Nevertheless, it is important to note that from a petrological point of view the latter quarries have a lot in common with the others (except for Sarab-e Dehlor), and that where they differ is in terms of composition, with high $\mathrm{MgO}$ and $\mathrm{SiO}_{2}$ contents as well as different amounts of trace elements. In fact, all the quarries consist of calcareous stone (limestone) with varying major constituents and amounts of impurities (minor/ trace constituents).

The analytical studies showed that the stones used in the construction of the Anahita Temple were from local sources. In fact, all the stone quarries and the stone cutting area around the Temple may have been used over the course of time to produce different types of stone 

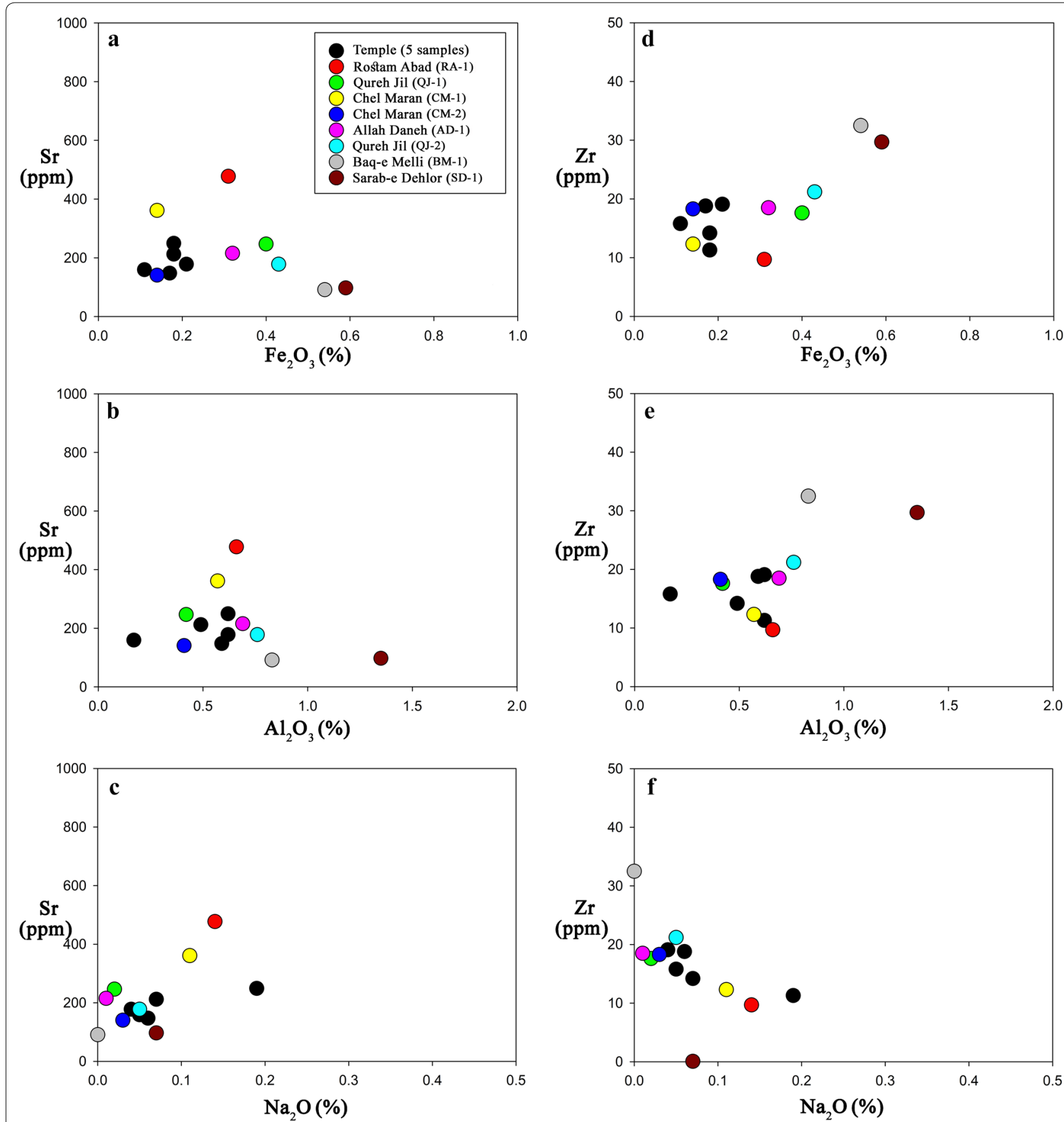

Fig. 9 Scatter plots of the chemical constituents of the samples based on XRF data, a $\mathrm{Fe}_{2} \mathrm{O}_{3} \mathrm{vs}$. Sr, $\mathbf{b} \mathrm{Al}_{2} \mathrm{O}_{3} \mathrm{vs}$. $\mathrm{Sr}_{1}, \mathbf{c} \mathrm{Na}_{2} \mathrm{O}$ vs. $\mathrm{Sr}_{\text {, }} \mathbf{d} \mathrm{Fe} \mathrm{O}_{2} \mathrm{O}_{3} \mathrm{vs}$. $\mathrm{Zr}$, e Al $\mathrm{O}_{3}$ vs. $\mathrm{Zr}$ and $\mathbf{f} \mathrm{Na}_{2} \mathrm{O}$ vs. $\mathrm{Zr}$

blocks used in the building. Nevertheless, some of the stone quarries, such as the western hill of the Chel Maran mountain and the Qureh Jil and Rostam Abad quarries may have been used more extensively. In addition, the survey of the local stone quarries in the Kangavar region shows that these three stone quarries were used more than the other areas [44]. This is clear to see from the remains of archaeological mining and quarrying in these three quarries. This indicates that the analytical data for the stone quarries matches much of the archaeological evidence uncovered in this region. Furthermore, evidence shows that building stone was extracted and cut to 
Table 5 Characterization of the analyzed stone samples from the Anahita Temple and the quarries based on four methods for the classification of calcareous stones

\begin{tabular}{|c|c|c|c|c|c|c|c|c|c|}
\hline & \multicolumn{3}{|c|}{ Classification method I } & \multicolumn{2}{|c|}{ Classification method II } & \multicolumn{2}{|c|}{ Classification method III } & \multicolumn{2}{|c|}{ Classification method IV } \\
\hline & $\mathrm{CaO}(\%)$ & $\mathrm{CaCO}_{3}(\%)$ & Type & $\mathrm{MgO}(\%)$ & Type & $\mathrm{CaO} / \mathrm{MgO}$ & Type & $\mathrm{CaCO}_{3}(\%)$ & Type \\
\hline $\mathrm{KN}-1$ & 54.49 & 96.79 & High purity & 0.77 & $\begin{array}{l}\text { Dolomitic lime- } \\
\text { stones }\end{array}$ & 70.77 & Limestone & 96.79 & Limestone \\
\hline $\mathrm{KN}-2$ & 54.22 & 96.31 & Medium purity & 0.41 & $\begin{array}{l}\text { Dolomitic lime- } \\
\text { stones }\end{array}$ & 132.24 & Limestone & 96.31 & Limestone \\
\hline $\mathrm{KN}-3$ & 54.95 & 97.60 & High purity & 0.49 & $\begin{array}{l}\text { Dolomitic lime- } \\
\text { stones }\end{array}$ & 112.14 & Limestone & 97.60 & Limestone \\
\hline $\mathrm{KN}-7$ & 54.91 & 97.53 & High purity & 0.8 & $\begin{array}{l}\text { Dolomitic lime- } \\
\text { stones }\end{array}$ & 68.64 & Limestone & 97.53 & Limestone \\
\hline $\mathrm{KN}-8$ & 53.56 & 95.13 & Medium purity & 0.74 & $\begin{array}{l}\text { Dolomitic lime- } \\
\text { stones }\end{array}$ & 72.38 & Limestone & 95.13 & Limestone \\
\hline RA-1 & 53.87 & 95.68 & Medium purity & 0.45 & $\begin{array}{l}\text { Dolomitic lime- } \\
\text { stones }\end{array}$ & 119.71 & Limestone & 95.68 & Limestone \\
\hline QJ-1 & 50.85 & 90.32 & Low purity & 0.49 & $\begin{array}{l}\text { Dolomitic lime- } \\
\text { stones }\end{array}$ & 103.78 & Limestone & 90.32 & Limestone \\
\hline QJ-2 & 52.47 & 93.20 & Medium purity & 0.41 & $\begin{array}{l}\text { Dolomitic lime- } \\
\text { stones }\end{array}$ & 127.98 & Limestone & 93.20 & Limestone \\
\hline CM-1 & 54.09 & 96.07 & Medium purity & 0.72 & $\begin{array}{l}\text { Dolomitic lime- } \\
\text { stones }\end{array}$ & 75.13 & Limestone & 96.07 & Limestone \\
\hline $\mathrm{CM}-2$ & 54.39 & 96.61 & High purity & 0.56 & $\begin{array}{l}\text { Dolomitic lime- } \\
\text { stones }\end{array}$ & 97.13 & Limestone & 96.61 & Limestone \\
\hline AD-1 & 50.47 & 89.64 & Low purity & 3.64 & $\begin{array}{l}\text { Slightly dolomitic } \\
\text { limestones }\end{array}$ & 13.87 & $\begin{array}{l}\text { Slightly dolomitic } \\
\text { limestone }\end{array}$ & 89.64 & Dolomitic limestone \\
\hline BM-1 & 39.23 & 69.68 & Impure & 8.34 & $\begin{array}{l}\text { Dolomitic lime- } \\
\text { stones sensu } \\
\text { stricto }\end{array}$ & 4.70 & Dolomitic limestone & 69.68 & $\begin{array}{l}\text { Impure dolomitic } \\
\text { limestone }\end{array}$ \\
\hline SD-1 & 51.61 & 91.67 & Low purity & 0.76 & $\begin{array}{l}\text { Dolomitic lime- } \\
\text { stones }\end{array}$ & 67.91 & Limestone & 91.67 & Limestone \\
\hline
\end{tabular}

Classification Method I [66]; Classification Method II [67]; Classification Method III [63, 68, 69] and Classification Method IV [62, 70,71]

size at these three quarries. Unfinished stone blocks similar to the finished blocks used in the Temple have also been discovered. This supports the hypothesis that these were the main stone quarries used in the construction of the Anahita Temple. The results of the analytical studies also matched the results of the archaeological studies very well.

It is also very interesting to note that the stone quarrying activities observed in Chel Maran and other quarries are very similar to those observed in the stone quarries near the Achaemenian sites including Persepolis and Pasargadae. These include cutting and carving the block into shape in the quarry and moving the unfinished blocks to the building for final preparations. Other clues include possible "signatures" of the stone workers on the surface of the blocks [3, 41]. Nevertheless, the quality of the stone working and the design in the Achaemenian sites was much better than that used in the Anahita Temple, which suggests that they date from different eras with less important rulers. It is clear that a lot more archaeological and scientific research is required on the Anahita Temple of Kangavar to find out more about the history of this site. Comparative studies on the architectural and technological aspects of this huge building could also be carried out in the future. This study shows that the application of scientific experimental studies is very useful for characterizing the technological and archaeological features of ancient buildings, in this case the Anahita Temple, especially in the field of ancient mining and for identifying the source of the raw materials used in stone constructions.

\section{Conclusion}

Archaeological and field studies conducted over the last decades in the Kangavar region of western Iran, have uncovered evidence of ancient stone quarries that may have been used as a source of materials for the largest and most famous ancient stone construction in this region, the Anahita Temple of Kangavar. An analytical study of the stone from the Anahita Temple and from nearby ancient stone quarries was performed to identify the different types of stone in a bid to ascertain the provenance of the many stone blocks used in the construction of this 
important archaeological complex. Results of mineralogical observations and chemical analyses showed that most of the stones used in the construction of the Temple are limestone with minor amounts of impurities such as $\mathrm{Mg}$ and $\mathrm{Si}$. Other stones can be considered as dolomitic limestone because they have a slightly higher $\mathrm{Mg}$ content. Calcite is the main mineral in the composition of the stone samples from the Temple and dolomite and silicate phases (quartz and clay minerals) were detected as minor phases or impurities. The study of the samples from the stone quarries showed various similarities between the stones from the Temple and the stones from the quarries from the chemical and mineralogical points of view. Nevertheless, the Chel Maran, Qureh Jil and Rostam Abad quarries, and in particular the western hill of Chel Maran mountain (sample CM-2) were probably the main sources of the stone blocks used in the Anahita Temple, although it is likely that limited amounts of stone were also obtained from the other quarries.

\section{Abbreviations}

XRD: X-ray diffraction; XRF: X-ray fluorescence.

\section{Acknowledgements}

The authors are thankful to F. Nazari, former Heads of the Anahita Temple of Kangavar World Heritage Research Center and V. Barnoos from the Art University of Isfahan, for their invaluable help. The research was financially supported by Research Group RNM179 of the Junta de Andalucía, Research Project MAT2016-75889-R of the Spanish Ministry of Economy, Industry and Competitiveness and also Research Project rent No. 956/4, financed by the Research Deputy of the Art University of Isfahan.

\section{Authors' contributions}

AS studied the thin section of the stone samples by microscopy methods, contributed to the preparing the draft of paper and also read the text, 00 prepared the samples, contributed in the analytical works and interpretation of the analytical data as well as preparing the draft of the paper, GC contributed to the chemical analyses and read and corrected the final paper, and MA collected the samples from quarries, provided photos of site and quarries and contributed to prepare samples for analyses. All authors read and approved the final manuscript.

\section{Funding}

This research was funded by Research Group RNM179 of the Junta de Andalucía, Research Project MAT2016-75889-R of the Spanish Ministry of Economy, Industry and Competitiveness as well as Research Project rent No. 956/4, financed by the Research Deputy of the Art University of Isfahan.

\section{Availability of data and materials}

The datasets used and/or analysed during the current study are available from the corresponding author on reasonable request.

\section{Competing interests}

The authors declare that they have no competing interests.

\section{Author details}

${ }^{1}$ Department of Conservation of Cultural and Historical Properties, Art University of Isfahan, Isfahan, Iran. ${ }^{2}$ Department of Petrology and Mineralogy, University of Granada, Granada, Spain.

Received: 15 October 2019 Accepted: 4 February 2020

Published online: 15 February 2020

\section{References}

1. Nylander C. Ionians in Pasargadae: studies in Old Persian Architecture. Boreas: Uppsala Studies in Ancient Mediterranean and Near Eastern Civilizations, 1, Uppsala; 1970.

2. Kleiss W. Construction materials and techniques in Persian architecture. Encycl Irani. 1992;2:217-9.

3. Tilia AB. A study on the methods of working and restoring stone and on the parts left unfinished in Achaemenian architecture and sculpture. East West. 1968;18(1-2):67-95.

4. Tilia AB. Studies and restorations at Persepolis and other sites of Fârs, Istituto Italiano per il Medio ed Estremo Oriente, Reports and Memoirs, XVI, Rome; 1972

5. Canepa MP. Dynastic sanctuaries and the transformation of iranian kingship between Alexanser and Islam. In: Babaie S, Grigor T, editors. Persian kingship and architecture, strategies of poser in Iran from Achaemenids to the Pahlavis. London: I. B. Tauris; 2015. p. 65-118.

6. Bier LD. The Sasanian palaces and their influence in early Islam. In: Babaie S, Grigor T, editors. Persian kingship and architecture, strategies of poser in iran from achaemenids to the Pahlavis. London: I. B. Tauris; 2015. p. 119-34.

7. Bier L. Sasanian palaces in perspective. Archaeology. 1982;35:29-36.

8. Huff D. Architecture III Sasanian period. Encycl Iran. 1986;3:329-34.

9. Hozhabri A. The evolution of religious architecture in the Sasanian period. Sasanika Archaeol. 2013; 18. https://www.sasanika.org/wp-content/uploa ds/e-sas-AR-18-The-EvolutionofReligiousArchitecture.pdf.

10. Kambakhshfard S. Kangavar Anahita Temple, Archaeological excavations and studies and architectural reconstruction and renovation of Anahita Temple and Taq-e Gara, ICHO Publications, Tehran, 1995. (In Persian)

11. The Editors of Encyclopaedia Britannica. Zagros Mountains. In: Encyclopædia Britannica. Encyclopædia Britannica Inc. https://www.britannica .com/place/Zagros-Mountains. Accessed 5 March 2019.

12. Waelkens M, Herz N, Moens L, editors. Ancient stones: quarrying, trade and provenance: interdisciplinary studies on stones and stone technology in Europe and Near East from the Prehistoric to the Early Christian Period. Acta Archaeologica Lovaniensia Monographiae. Leuven: Leuven University Press; 1992.

13. Tykot R. Scientific methods and applications to archaeological provenance studies. In: Martini M, Milazzo M, Piacentini M, editors. Proceedings of the international school of physics "Enrico Fermi" Course CLIV. Amsterdam: IOS Press; 2004. p. 407-32.

14. Kolb CC. Provenance Studies in Archaeology. In: Smith C, editor. Encyclopedia of Global Archaeology. New York: Springer; 2014. https://doi. org/10.1007/978-1-4419-0465-2_327.

15. Bloxam E, Storemyr P. Old Kingdom basalt quarrying activities at Widan el-Faras, Northern Faiyum Desert. Journal of Egyptian Archaeology. 2002:88:23-36

16. Harrell JA, Storemyr P. Ancient Egyptian quarries - an illustrated overview. In: Abu-Jaber N, Bloxam EG, Degryse P, Heldal T, editors. QuarryScapes: ancient stone quarry landscapes in the Eastern Mediterranean, vol. 12. Trondheim: Geological Survey of Norway Special Publication; 2009. p. 7-50.

17. Heldal T, Bloxam E, Storemyr P, Kelany A. The Geology and Archaeology of the Ancient Silicified Sandstone Quarries at Gebel Gulab and Gebel Tingar, Marmora: an International Journal for Archaeology. History and Archaeometry of Marbles and Stones. 2005;1:11-35.

18. Steponaitis VP, Irwin JD, McReynolds TE, Moore CR. Stone Quarries and Sourcing in the Carolina Slate Belt, Research Report 25. Research Laboratories of Archaeology. Chapel Hill: University of North Carolina; 2006.

19. Polikreti K, Maniatis Y, Bassiakos Y, Kourou N, Karageorghis V. Provenance of archaeological limestone with EPR spectroscopy: the case of the Cypriote-type statuettes. J Archaeol Sci. 2004;31:1015-28.

20. Johnson PR, Pearl FB, Eckert SL, James WD. INAA of pre-contact basalt quarries on the Samoan Island of Tutuila: a preliminary baseline for an artifact-centered provenance study. J Archaeol Sci. 2007;34:1078-86.

21. Ricca M, Belfiore CM, Ruffolo SA, Barca D, De Buergo MA, Crisci GM, La Russa MF. Multi-analytical approach applied to the provenance study of marbles used as covering slabs in the archaeological submerged site of Baia (Naples, Italy): the case of the "Villa con ingresso a protiro". Appl Surf Sci. 2015;357:1369-79.

22. Jefferson D, Henry A. Sourcing Stone for Historic Building Repair. London: Historic England; 2006. 
23. Ashurst J, Dimes FJ. Conservation of Building and Decorative Stones. London: Butterworth Heinemann; 1990.

24. Hyslop E. Sourcing and Selection of Stone for Repair. In: Henry A, Pearce J, editors. Stone Conservation, Principles and Practice. Routledge: London and New York; 2015. p. 89-100.

25. Zöldföldi J, Hegedüs P, Székel B. Interdisciplinary data base of marble for archaeometric, art historian and restoration use. In: Yalcin Ü, Özbal H Pasamehmetoglu G, editors. Ancient Mining in Turkey and the Eastern Mediterranean. Ankara: Atilim University; 2008. p. 225-51.

26. Antonelli F, Lazzarini L, Cancelliere S, Dessandier D. Volubilis (Meknes, Morocco): archaeometric study of the white and coloured marbles imported in the Roman age. Journal of Cultural Heritage. 2009;10:116-23.

27. Lazzarini L. Archaeometric aspects of white and coloured marbles used in antiquity: the state of the art. Periodico di Mineralogia. 2004;73:113-25.

28. Corremans M, Degryse P, Wielgosz D, Waelkens M. The import and the use of white marble and coloured stone for wall and floor, revetment at Sagalassos. In: A. G. Garcia-M., P. L. Mercadal, I. R. de Llanza, Eds. Interdisciplinary Studies on Ancient Stone Proceedings of the IX Association for the Study of Marbles and Other Stones in Antiquity (ASMOSIA) Conference, Tarragona 2009. Tarragona: Institut Català d'Arqueologia Clàssica; 2012, pp 38-51.

29. Pensabene P, Antonelli F, Lazzarini L, Cancelliere S. Archaeometric analyses of white marbles from Hadrian's Villa (Tivoli, Italy) and the use of Pentelic and Dokymaean Marbles in the statuary of the so-called Canopus, In Interdisciplinary Studies on Ancient Stone Proceedings of the IX Association for the Study of Marbles and Other Stones in Antiquity (ASMOSIA) Conference, Tarragona 2009, A. G. Garcia-M., P. L. Mercadal, I. R. de Llanza (Eds.), Institut Català d'Arqueologia Clàssica, Tarragona, 2012, 104-108.

30. Gaied ME, Younes A, Gallala W. A geoarchaeological study of the ancient quarries of Sidi Ghedamsy Island (monastir, Tunisia). Archaeometry. 2010;52:531-49.

31. Gaied ME, Gallala W, Younès A. Geoarchaeology of Roman Underground Quarries at Ksour Essaf (Tunisia). Geoheritage. 2015;7:375-82.

32. Gallala W, Younès A, Gaied ME, Hadjzobir S, Sparks K, Molli G. A multianalytical approach for determining the provenance of the marbles from Ruspina Roman baths (Monastir, Tunisia). Archaeological and Anthropological Sciences. 2017;9:1275-85.

33. Antonelli F, Gentili G, Renzulli A, Amadori ML. Provenance of the ornamental stones used in the baroque church of S Pietro in Valle (Fano, Central Italy) and commentary on their state of conservation. Journal of Cultural Heritage. 2003:4:299-312.

34. Gliozzo E, Grassi N, Bonanni P, Meneghini C, Tomei MA. Gemstones from Vigna Barberini at the Palatine Hill (Rome, Italy). Archaeometry. 2011;53:469-89.

35. Pappalardo L, Karydas AG, Kotzamani N, Pappalardo G, Romano FP, Zarkadas Ch. Complementary use of PIXE-alpha and XRF portable systems for the non-destructive and in situ characterization of gemstones in museums. Nucl Instrum Methods Phys Res, Sect B. 2005;239:114-21.

36. Emami SM. Preliminary studies on mining methods used in Sivand quarries during the Achaemenian period in Fars province, Irán. Geología Colombiana - An International Journal on Geosciences. 2010:35:175-85.

37. Emami M, Eslami M, Fadaei H, Karami HR, Ahmadi K. MineralogicalGeochemical Characterization and Provenance of the Stones Used at the Pasargadae Complex in Iran: a New Perspective. Archaeometry. 2018;60:1184-201.

38. Rashidi Nejad M, Khademi Nadooshan F, Khazaie M, Masjedi P. An Archaeometrical Analysis of the Column Bases from Hegmatâneh to Ascertain their Source of Provenance. Interdisciplinaria archaeologica: Natural Sciences in Archaeology. 2012;3:221-7.

39. Ebrahimi Q, Mohammadi Qasrian S. Identification of a Late Sasanian stonecutting workshop at Taq-E Bostan, Kermanshah, Iran, Antiquity Project Gallery, 90 (350), 2016, https://www.antiquity.ac.uk/projg all/ebrahimi350.

40. Heidari M, Torabi-Kaveh M, Mohseni H. Assessment of the Effects of Freeze-Thaw and Salt Crystallization Ageing Tests on Anahita Temple Stone, Kangavar, West of Iran. Geotech Geol Eng. 2017;35:121-36.

41. Oudbashi O. Ancient Stone Quarry in Chehel Maran closed by Kangavar Archaeological complex (Anahita Temple), west of Iran, In: Proceedings of International Conference of Ancient Mining in Turkey and eastern Mediterranean, June 15-22 2008, Ankara, ATILIM university Publications; 2008, 371-381.

42. Shekofteh A, Oudbashi O, Cultrone G, Ansari M. Analytical Studies on the Chel Maran Ancient Stone Quarry and Comparison with the Stones of the Anahita Temple of Kangavar. Parseh Journal of Archaeological Studies. 2019;9:109-27 (in Persian).

43. Huff D. Pre-Islamic Quarry- and Stone-technology in Iran, In Persiens Antike Pracht, Bergbau Hand-werk Archaologie, Katalogbeitrage in englischer sparche. Bochum: Dautsches Bergbau-museum; 2004. p. 294-309.

44. Nazari F, Doostani S. A Study of the Stone Quarries of the Anahita Temple of Kangavar. Asar. 2007;42-43:52-64 (In Persian).

45. Mehryar M, Kabiri A. Continuation of Excavations in Kangavar Anahita Temple. PAJOOHASHGAH: ICHTO; 2004 (In Persian).

46. Kambakhshfard S. Kangavar. In: Kiani MY, editor. Iranian Cities. Tehran: Jahad-e Daneshgahi Press; 1989. p. 107-50 (In Persian).

47. Azarnoush M. Excavations at Kangavar. Archaologische Mitteilungen aus Iran. 1981;14:69-94.

48. Azarnoush M. New Evidence on the Chronology of the "Anahita Temple". Iranica Antiqua. 2009:44:393-402.

49. Schmitt R. Isidorus of Charax, In Encyclopaedia Iranica, Yarshater, E (Ed.). XIV. 2007;2:125-7.

50. Kleiss W. Kangavar. Encyclopaedia Iranica. 2010;5:496-7.

51. Stöcklin J. Possible ancient continental margins in Iran. The geology of continental margins. Berlin: Springer; 1974. p. 873-87.

52. Stöcklin J. Structural history and tectonics of Iran; a review. Am Asso Petrol Geol Bull. 1968;52:1229-58.

53. Ashayeri I, Biglari M, Shamoradi SB, Rashidi Gouya H. Probabilistic Seismic Hazard Assessment and Geotechnical Seismic Micro-zonation of Kangavar with Ambient Vibration and Electrical Resistivity Analysis. AUT Journal of Civil Engineering. 2018:2(1):29-38.

54. Gholamhosein Fard N, Sorbi A, Arian M. Active Tectonics of Kangavar Area. West Iran. Open Journal of Geology. 2015;5:422-41.

55. Nezafati N. Au-Sn-W-Cu-Mineralization in the Astaneh-Sarband Area, West Central Iran, including a comparison of the ores with ancient bronze artifacts from Western Asia, Ph.D. thesis, Eberhard-Karls-Universität Tübingen, 2006.

56. Tizro TA, Voudouris KS, Kamali M. Comparative Study of Step Drawdown and Constant Discharge Tests to Determine the Aquifer Transmissivity: the Kangavar Aquifer Case Study. Iran, Journal of Water Resource and Hydraulic Engineering. 2014;3(1):12-21.

57. Stocklin J, Nabavi MH, Tectonic Map of Iran, Geological Survey of Iran, 1973.

58. Shapur Shahbazi A. The Authoritative Guide to Persepolis. Tehran: Safiran; 2004.

59. Flügel E. Microfacies of Carbonate Rocks, Analysis, Interpretation and Application. With a contribution by A. Munnecke. 2nd ed. Berlin: Springer; 2010.

60. Takahashi G. Sample preparation for X-ray fluorescence analysis III. Pressed and loose powder methods, Rigaku Journal. 2015;31(1):26-30.

61. Bausch WM. Clay content and calcite crystal size of limestones. Sedimentology. 1968;10:71-5.

62. Geyssant J. Geology of Calcium Carbonate, from Mineral to Rock-the Deposits, in Calcium Carbonate, from the Cretaceous Period into the 21 th Century, Tegethoff, F. W. (Ed.), in collaboration with J. Rohleder and E. Kroker, Springer, Basel, 2001, 1-52.

63. Chilingar GV. Classification of Carbonate Rocks on Basis of Chemical Composition: NOTES. J Sediment Petrol. 1960;30(1):157-8.

64. Germinario L, Hanchar JM, Sassi R, Maritan L, Cossio R, Borghi A, Mazzoli C. New petrographic and geochemical tracers for recognizing the provenance quarry of trachyte of the Euganean Hills, northeastern Italy. Geoarchaeology. 2018:33:430-52.

65. Vaggelli G, Serra M, Cossio R, Borghi A. A New Approach for Provenance Studies of Archaeological Finds: inferences from Trace Elements in Carbonate Minerals of Alpine White Marbles by a Bench-to-Top -XRF Spectrometer. International Journal of Mineralogy. 2014. https://doi. org/10.1155/2014/217916.

66. Cox FC, Bridge McC, Hull JH. Procedures for the assessment of limestone resources. Institute of Geological Sciences, Mineral Assessment Report 30, 1977, 20 pp. 
67. Miche H, Simler R, Affaton P, Mickala O, Boudzoumou F, Mbina M. New Computerized Method for the Geochemical Classification of Precambrian Carbonate Rocks: case of a Set of African Cap Carbonates. International Journal of Geosciences. 2013;4(10A):1-13.

68. Chilingar GV. Classification of limestones and dolomites on basis of $\mathrm{Ca} /$ Mg ratio. J Sediment Res. 1957;27(2):187-9.

69. Frolova EK. On classification of carbonate rocks of limestone-dolomltemagnesite series: novosti Neft. Tekhniki (Geology). 1959;3:34-5.

70. Carr DD, Rooney LF, Freas RC. Limestone and Dolomite, Industrial Minerals and Rocks, Society for Mining, Metallurgy and Exploration. 6th ed. Littleton: Colorado; 1994. p. 605-29.
71. Freas RC, Hayden JS, Pryor CA Jr. Limestone and Dolomite. In: Kogel JL, Trivedi NC, Barker JM, Krukowski ST, editors. Industrial Minerals and Rocks, Commodities, Markets and Uses. 7th ed. Littleton: Society of Mining, Metallurgy and Exploration Inc; 2006. p. 581-97.

\section{Publisher's Note}

Springer Nature remains neutral with regard to jurisdictional claims in published maps and institutional affiliations.

\section{Submit your manuscript to a SpringerOpen ${ }^{\circ}$ journal and benefit from:}

- Convenient online submission

- Rigorous peer review

- Open access: articles freely available online

- High visibility within the field

- Retaining the copyright to your article

Submit your next manuscript at $\boldsymbol{\nabla}$ springeropen.com 